\title{
The Legal Framework of United Nations Financing: Peacekeeping and Penury ${ }^{\dagger}$
}

\author{
John H. Jackson* \\ The expenses of the Organization shall be borne by the Members.... \\ -U.N. Charter, article 17
}

$\mathrm{T}$ HIS CRYPTIC phrase has been the source of one of the most puzzling controversies of international law to arise in the past few years. Although an advisory opinion of the International Court of Justice interpreting this phrase was handed down last July, ${ }^{1}$ the issues involved are by no means settled. The so-called "U.N. financial crisis" still exists. ${ }^{2}$

As a backdrop to these issues, this article analyzes the legal framework of United Nations financing as it presently exists in the charter, resolutions, and practice of that Organization, and in significant United States legislation. To understand this subject is exceptionally difficult because the relevant information is scattered in a wide variety of sources, ${ }^{3}$ and often is buried deep in complex documentary systems. A subsidiary purpose of this article, therefore, is to gather references to these sources and to set forth the most salient available information in an orderly fashion. For this reason, as well as the necessity of protecting information conveyed in con-

† The author is deeply indebted for lengthy discussions on the subject matter of this article to members of the United States delegation to the United Nations and officials in the Department of State, particularly Albert F. Bender, Richard N. Gardner, Frank K. Hefner, Virginia Westfall, and Wilber H. Ziehl. The author, however, takes responsibility for everything in this article. The author also gratefully acknowledges the financial assistance afforded hin for expenses of research by the International Legal Studies Committee of the University of California School of Law, Berkeley.

* Acting Associate Professor of Law, University of California School of Law, Berkeley.

1 Certain Expenses of the United Nations, [1962] I.C.J. Rep. 151.

2 See discussion in part VI, following note 205 infra.

3 Several works are useful for an understanding of the historical and structural aspects of U.N. finances and the "crisis." These include: NICHots, FInANcIng the UNITED Nations: Problemss and Prospects (M.I.T., Center for Int'l Studies 1961); Singer, Finatrcing Internatronal Organizatton: THE Untxed Nattons Budget Process (1961); Stoessinger, Financing the United Nations, INT'L CoNc., No. 535, at 3 (Nov. 1961). For a discussion of the International Court of Justice advisory opinion on U.N. expenses, [1962] I.C.J. Rep. 151, see Hogg, Peace-Keeping Costs and Charter Obligations-Implications on the International Court of Justice Decision on Certain Expenses of the United Nations, 62 CoLUM. L. REv. 1230 (1962). See also Miller, Legal Aspects of the United Nations Action in the Congo, 55 Axs. J. INT'1 L. 1 (1961); Singer, The Finances of the League of Nations, 13 INT'I ORG. 255 (1959).

The Brookings Institute is planning the publication in late 1963 of a volume on the financing of the United Nations system, under the authorship of John G. Stoessinger. 
fidence, only information set forth in the public record has been included here. Yet much of this information itself is so difficult to find, and is known to so few people, that it will undoubtedly provide a few surprises even to the informed reader.

The article is divided into the following parts:

I. U.N. Charter History

II. The Structure and Authority of U.N. Budgeting

III. U.N. Financial Sources

VI. United States Contributions to the U.N.

V. Development of the Financial Crisis

VI. The World Court Opinion and Its Aftermath

VII. Reflections

\section{I}

U.N. CHARTER HISTORY

The express references to finances in the United Nations Charter are contained in articles 17,18 , and 19 which read:

\section{Article 17:}

1. The General Assembly shall consider and approve the budget of the Organization.

2. The expenses of the Organization shall be borne by the Members as apportioned by the General Assembly.

3. The General Assembly shall consider and approve any financial and budgetary arrangements with specialized agencies referred to in Article 57 and shall examine the administrative budgets of such specialized agencies with a view to making recommendations to the agencies concerned.

Article 18:

2. Decisions of the General Assembly on important questions shall be made by a two-thirds majority of the members present and voting. These questions slall include: . . . budgetary questions.

\section{Article 19:}

A member of the United Nations which is in arrears in the payment of its financial contributions to the Organization shall lave no vote in the General Assembly if the amount of its arrears equals or exceeds the amount of the contributions due from it for the preceding two full years. The General Assembly may, nevertheless, permit such a Member to vote if it is satisfied that the failure to pay is due to conditions beyond the control of the Member. 
Experience of the League of Nations was influential in drafting the U.N. Charter. ${ }^{4}$ Article 6 of the League Covenant provided initially that "the expenses of the Secretariat shall be borne by the menbers of the League in accordance with the apportionment of expenses of the International Bureau of the Universal Postal Union." This was amended in 1924 , however, to read, "The expenses of the League shall be borne by the Members of the League in the proportion decided by the Assembly." In addition, the League Covenant empowered the Council to "include as part of the expenses of the Secretariat the expenses of any bureau or commission which is placed under the direction of the League."

The League had to solve three major problems as a result of the covenant provisions on financing: (1) The initial language of apportionment which proved unwieldy and had to be replaced; (2) the allocation of power over finances between the Council and the Assembly; and (3) the problem of the unanimous vote required to approve the budget (and all other measures).

The first, as stated, was solved by an amendnient to the covenant. The second problem was resolved ultimately by a system whereby the Council automatically passed on to the Assenbly budgets approved by a Supervisory Commission of experts, which was appointed solely by the Assembly's Fourth (Financial and Budgetary) Committee. ${ }^{8}$ The third problem was resolved by a "tacit understanding" that a state dissenting from adoption of a recommended budget would abstain, and thereby not be counted under the rules for purposes of ascertaiming unanimity. ${ }^{9}$ By this means paralysis was averted.

The U.N. Charter avoided these three problems from the outset. Although some initial drafts of financial provisions for a U.N. Charter would have provided for joint Assembly-Council control, ${ }^{10}$ by the time of the Dumbarton Oaks Conference express references on financial control were proposed for the Assembly alone. ${ }^{11}$ Voting on the budget evolved in early drafts from a two-thirds requirement, ${ }^{12}$ to a majority, ${ }^{13}$ to a weighted voting scheme based on size of contribution, ${ }^{34}$ until finally the present two-

4 See generally Russell \& Muther, A History of tHe United Natrons Charter (1958).

5 Aufricet, Gume to League of Nations Publications 95 (1951).

${ }^{B}$ League of Nations Covenant art. 6; see Aurricit, op. cit. supra note 5, at 95.

7 League of Nations Covenant art. 24, para. 3.

${ }^{8}$ Singer, Financing International Organdzation: The United Natrons Budget ProCESS 2 (1961).

8 SINGer, The Finances of the League of Nations, supra note 3, at 263.

10 RUSSEII \& MUTHER, op. cit. supra note 4, at 377 .

11 Ibid.

12 SInger, op. cit. supra note 8 , at 3.

13 Ibid.

14 RUSSELI \& MUTHER, op. cit. supra note 4, at 378. 
thirds vote was established at the San Francisco Conference. ${ }^{15}$ The details of apportionment of expenses were deliberately omitted from the charter and left to decision of the General Assembly by the San Francisco Conference, as it was considered unwise to set forth such detail in the basic document. ${ }^{16}$

There are some other significant changes in the charter from the League Covenant. The charter, unlike the covenant, leaves to the specialized agencies control of their individual budgets, allowing only General Assembly recommendations. ${ }^{17}$ The League Assembly had exercised supervisory control over specialized agency budgets. ${ }^{18}$

A second important innovation in the U.N. Charter originated at the San Francisco Conference. Due to a suggestion by the Advisory Committee of Jurists, the obligation of members to bear the expenses of the organization was more clearly stated. ${ }^{19}$ Langnage that in a prior draft read, "The General Assembly shall apportion the expenses among the members of the Organization," was changed to read, "The expenses of the Organization shall be borne by the members as apportioned by the General Assembly."

Significant also is the loss-of-vote sanction for two year's arrears, provided in article 19 , accepted after discussion of several variants. ${ }^{20}$

\section{II}

\section{THE STRUCTURE AND AUTHORITY OF U.N. BUDGETING}

The General Assembly's financial regulations, augmented by rules of the Secretary-General promulgated pursuant to General Assembly authority, have established the budgetary and financial processes of the U.N.21

The United Nations superintends a myriad of funds, accounts, and

15 Id. at 862 ; U.N. CEARTER art. 18.

16 Doc. No. $415, \mathrm{II} / 1 / 18,8$ U.N. CoNf. INT'L ORG. Docs. [hereinafter cited as U.N.C.I.O.] 353 (1945); RUSSEL \& MUTHER, op. cit. supra note 4, at 863.

17 U.N. Charter art. 17, para. 3. Coinpare League of Nations Covenant art 24, para. 1: "There shall be placed under the direction of the League all international bureaus already established by general treaties if the parties to such treaties consent."

18 See the portion of League of Nations Covenant art. 24 quoted in the text accounpanying note 7 supra.

198 U.N.C.I.O. 487 (1945): "In taking this action, the coinmittee considered the view of the Advisory Committee of Jurists that a clear statement of the obligation of meinbers to meet the expenses of the Organization should be found in the Charter." Sce also id. at 495 (second report of the rapporteur of Committee II/1).

${ }^{20}$ See 8 U.N.C.I.O. 35, 249, 265, 409, 419, 428, 453, 457, 541 (1945); 11 id. at 596.

${ }^{21}$ Secretary-General's Bulletin, Financial Regulations and Rules of the U.N., U.N. Doc. No. ST/SGB/Financial Rules/1 (1960). Hereinafter, the regulations and rules (promulgated by resolution of the General Asseunbly) will be cited as U.N. Fin. Reg. and U.N. Fin. Rules. The U.N. document system is explained well in Brararer, WaII, CaAMrberin \& Hovet, A Guide to the Use of UNIted Nations Documents (1962). 
budgets. For instance, the latest Financial Report and Accounts ${ }^{22}$ contains reports of seven major categories of funds and accounts, each of which is financed in a separate way. Some of these can be further subdivided, so that in all about twenty-two funds must be kept separate under U.N. accounting. ${ }^{23}$ One fund is the Library Endowment Fund. Another is the United Nations Fund for the Congo, ${ }^{24}$ which nuust be kept separate from the Ad Hoc Account for the United Nations Operations in the Congo because the former is financed basically by voluntary contributions and is used for economic and public aid, while the latter depends heavily on assessed contributions and is used for the U.N. military operation in the Congo. ${ }^{25}$ These several funds comprise an annual budget in excess of $\$ 400$ million. The budgets of the "specialized agencies," such as UNESCO, FAO, and IIO, total another $\$ 80$ million or niore per year. ${ }^{\mathbf{2 6}}$

There are, however, three basic expenditure funds or accounts which are generally considered together in press and other commentaries about U.N. financing. These are the three U.N. funds which are financed by assessments to members, namely: the United Nations General Fund (or regular budget) ${ }^{27}$ the Special Account for the United Nations Emergency Force (the U.N. operation in the Middle East, hereinafter termed UNEF) ${ }^{28}$ and the Ad Hoc Account for the United Nations Operations in the Congo (Opérations des Nations Unies au Congo, hereinafter termed ONUC). ${ }^{29}$ This article will primarily discuss these three funds and the Working Capital Fund.

22 Financial Report and Accounts for the Year Ended 31 December 1961 and Report of the Board of Auditors, U.N. GeN. Ass. OFF. Rec. 17th Sess., Supp. No. 6 (A/5206) (1962).

23 See generally Note by the Secretary-General, Budgetary and Financial Practices of the United Nations, U.N. Doc. No. A/AC.113/1 (Jan. 21, 1963). This document gives a short description of each of the twenty-one trust funds, reserve and special accounts, plus the regular budget. See note 124 infra.

24 Established by U.N. Gen. Ass. Res. No. 1474 (ES-IV) (1960). Provisional financial rules of the U.N. Fund for the Congo (not ONUC, see text accompanying note 29 infra) exist as promulgated by the Secretary-General with effect from April 12, 1961. See U.N. Doc. No. ST/SGB/CONGO FUND/1 (1961).

Note: Resolutions of the General Assembly are numbered serially, from the origin of the U.N. on. The session in which the resolution was adopted is expressed in Roman numerals and placed in parentheses after the resolution number. E.g., U.N. Gen. Ass. Res. No. 1122 (XI) (1956).

25 The Ad Hoc Account for the U.N. Operations in the Congo (ONUC) was established by U.N. Gen. Ass. Res. No. 1583 (XV) (1960), and carried forward by other resolutions. See text accompanying notes 167-69, 203 infra. The current ONUC appropriation resolution is U.N. Gen. Ass. Res. No. 1865 (XVII) (Dec. 20, 1962).

28 House Comm. on Foreign Affairs, United States Contributions to International Organizations, H.R. Doc. No. 460, 87th Cong., 2d Sess. 138-39 (1962).

27 U.N. Fin. Reg. No. 6.1.

28 U.N. Gen. Ass. Res. No. 1122 (XI) (1956).

29 U.N. Gen. Ass. Res. Nos. 1583 (XV) (1960); 1619 (XV) (1961) ; 1732 (XVI) (1961). 


\section{A. What to Spend: The Budget}

Although the General Assembly gives final approval to the budget, ${ }^{30}$ the budget formulation process involves the Secretariat, and at least two subsidiary bodies of the General Assembly, the Fifth Committee and the Advisory Committee on Administrative and Budgetary Questions (ACABQ). The Fifth Committee, one of six "main Committees" of the General Assembly composed of a representative from each U.N. member, is called the Administrative and Budgetary Committee, a name that basically defines its area of competence. ${ }^{31}$ The $A C A B Q$ is a committee of twelve appointed by the General Assembly to assist the Fifth Committee and to oversee the budget in various ways. Members include representatives of the major powers in the U.N. ${ }^{32}$

The U.N. budget process for the General Fund, which covers the annual regular U.N. administrative expenses and some small programs, is operated on a calendar year basis, ${ }^{33}$ and can be outlined as follows:

(1) Heads of departments submit estimates to the controller. This must be accomplished in the Spring preceding the budget year. ${ }^{34}$

(2) The Office of the Controller submits recommended estimates to the Secretary-General for presentation to the General Assembly. ${ }^{35}$

(3) The Secretary-General decides on the estimates to be submitted. He must submit them to the ACABQ twelve weeks prior to the regular session of the General Assembly. ${ }^{36}$

(4) The ACABQ considers the estimates and reports upon them to the General Assembly. This report, along with the estimates, must be submitted to all member States at least five weeks prior to the regular General Assembly session. ${ }^{37}$

30 U.N. Charter art. 17.

31 U.N. Gen. Ass. Rules of Procedure [hereinafter cited as Gen. Ass. Rules], U.N. Doc. No. A/4700 (1961) (embodying amendments and additions adopted by the General Assembly through Dec. 31, 1960). See Gen. Ass. Rules No. 101 ; Gen. Ass. Rules No. 156, as amended, U.N. Gen. Ass. Res. No. 1659 (XVI) (1961).

32 The meinbership of the Advisory Committee on Administrative and Budgetary Questions for 1962 was as follows: Chairman: H. E. Mr. Thanassis Aghnides (Greece); Members: Mr. Mohamad Abdel Magid Ahmed (Sudan); Mr. Albert F. Bender, Jr. (U.S.); M. André Ganem (France); Sr. Don Alfonso Grez (Chile); Mr. C.H.W. Hodges (United Kingdom); Mr. Ismat T. Kittani (Iraq) ; Dr. Raúl A. J. Quijano (Argentina); Mr. E. Olu Sanu (Nigeria); M. Dragos Serbanescu (Romama); Mr. Agha Shahi (Pakistan); and Mr. A.F. Sokirkin (U.S.S.R.). See Permanent Missions to the United Nations, U.N. Doc. No. ST/SG/SER.A/149 (1962). At the 17th General Assembly, the following new members were appointed: M. André Ganem (France) ; Mr. James Gibson (United Kingdom); Mr. Ismat T. Kittani (Iraq); Mr. Agha Shahi (Pakistan). U.N. Gen. Ass. Res. No. 1791 (XVII) (Dec. 11, 1962).

33 U.N. Fin. Reg. No. 2.1.

34 U.N. Fin. Rules No. 103.2 .

35 U.N. Fin. Rules No. 103.3.

36 U.N. Fin. Reg. No. 3.5. The General Assembly regularly convenes on the third Tuesday in September. Gen. Ass. Rules No. 1.

37 U.N. Fin. Reg. Nos. 3.4, .6. 
(5) The budget estimates and ACABQ report are referred by the General Assembly to the Fifth Committee. ${ }^{38}$

(6) The Fifth Committee reports a recommended budget resolution, along with other financial resolutions, to the plenary General Assembly where they are usually adopted with a minimum of debate, late in the session..$^{39}$

Critical elements in the process of evaluating Secretariat budget requests are the work of the ACABQ and the Fifth Committee. What power do these committees have and how do they function?

According to General Assembly rule 158, the ACABQ is "responsible for expert examination of the budget of the United Nations, and shall assist the Administrative and Budgetary Committee of the General Assembly." In that capacity it has a variety of functions, the central one being review of the Secretary-General's budget.

Perhaps due to the relative ease with which it can be called together during any period of the year, ${ }^{40}$ and due also to the fact that its members have developed expertise in the subject of U.N. finances, the U.N. General Assembly has delegated to the ACABQ some key powers in addition to its functions in the annual budget process. For instance, although the financial regulations provide that there shall be no transfer of credits or funds between appropriation sections in the budget without General Assembly approval," the annual budget invariably states: "The Secretary-General is authorized: .... (b) To transfer credits between sections of the budget with the prior concurrence of the Advisory Committee on Administrative and Budgetary Questions." ${ }^{32}$ Another example of delegation to the ACABQ is the annual resolution that authorizes the Secretary-General to incur

38 U.N. Gen. Ass. Rules No. 99. See allocation of agenda items of the 17th General Assembly, U.N. JourwaL No. 2990, Supp. No. 2 (Sept. 26, 1962), approved by the General Assembly, U.N. GeN. Ass. OfF. REc. 17th Sess., Plenary 87-126 (A/PV.1129) (provisional) (Sept. 24, 1962). The budget estimates for the financial year 1963, considered by the 17th General Assembly, were its agenda item No. 62 .

39 U.N. Fin. Reg. No. 3.7; see U.N. GEN. Ass. OFF. Rec. 17th Sess., Plenary (A/PV.1201) (Dec. 20, 1962). The 17th General Assembly closed at its 1202d meeting, Dec. 20, 1962, in the evening.

40 During 1962 the ACABQ held three series of meetings: The first in Geneva in the spring on some special problems of the European office of the U.N., the second in New York during the summer to consider the Secretary General's 1963 budget estimates, and the third during the 17th General Assembly session in New York, Sept. 17th to Dec. 20th. See ACABQ, Seventh Report to the General Assembly at its Seventeenth Session, U.N. GEN. Ass. OFF. Rec. 17th Sess., Supp. No. 7, at $v(A / 5207)$ (1962).

41 U.N. Fin. Reg. No. 4.5.

42 U.N. Gen. Ass. Res. No. 1861, para. 2 (XVII) (1962). See also U.N. Gen. Ass. Res. No. 1734, para. 2 (XVI) (1961); and prior budget resolutions: 1584 (XV) (1960); 1443 (XIV) (1959); 1338 (XIII) (1958); 1230 (XII) (1957); 1083 (XI) (1956); 979 (X) (1955); etc. 
extrabudgetary commitments which are "unforeseen and extraordinary," "with the prior concurrence of" the ACABQ. ${ }^{43}$

The Fifth Committee, in contrast to the ACABQ, is a main committee of the General Assembly, and sits only while the General Assembly itself is in session. Composed of one representative from each member nation (the membership now numbers 110), ${ }^{44}$ this committee must necessarily function in a more elaborate and public manner. The sessions of the Fifth Committee are open to the public, while those of the ACABQ are closed. ${ }^{45}$ The large size of the Fifth Committee brings with it the usual slowness of work - a tendency to get meetings started half an hour or more late each session, more speeches, and procedural delays. ${ }^{46}$

After receiving $A C A B Q$ recommendations, the Fifth Committee discusses the budget, item by item, over a period of weeks, taking an approval vote upon the "first reading" of each item. ${ }^{47}$ At the end of the session, after all revisions are in, mcluding those necessitated by contemporaneous decisions of the General Assembly, the committee votes on the budget at one time, section by section, in a "second reading." 48

One rule of General Assembly procedure could conceivably give the Fifth Committee a central place in the U.N. power structure-this is rule

43 U.N. Gen. Ass. Res. No. 1862, para. 1 (XVII) (1962). Prior resolutions of a similar nature are Nos. 1735 (XVI) (1961); 1585 (XV) (1960); 1444 (XIV) (1959); 1339 (XIII) (1958) ; 1231 (XII) (1957); 1084 (XI) (1956); 980 (X) (1955); etc. Since a 1960 resolution, U.N. Gen. Ass. Res. No. 1615 (XV) (1960), the "unforeseen and extraordinary expenses" resolutions have stipulated that if "as a result of a decision of the Security Council, commitinents relating to the maintenance of peace and security should arise in an estimated total exceeding $\$ 10$ million" before the next session of the General Assembly, the Assembly shall be convened by the Secretary-General to consider the matter. See U.N. Gen. Ass. Res. No. 1862, para. 3 (XVII) (1962). The same resolutions authorize the Secretary-General to make commitments relating to the maintenance of peace and security up to $\$ 2$ million without prior ACABQ concurrence.

Other examples of delegation to the $A C A B Q$ of "concurring" or other powers include: U.N. Gen. Ass. Res. Nos. 1863, paras. 4(c)-(d) (XVII) (1962) (Working Capital Fund); 1727, para. 6 (XVI) (1961) (United Nations International School).

44 Gen. Ass. Rules No. 102; see, e.g., the notice of meetings for the Fifth Committee and the ACABQ, U.N. Journat No. 3028, at 1-2 (Nov. 17, 1962).

45 See, e.g., U.N. Journat No. 3004, at 1 (Oct. 16, 1962), listing meetings of the Fifth Committee (open) and the ACABQ (closed).

46 For example, the proposal under discussion must generally be circulated at least one day in advance of the meeting. Gen. Ass. Rules No. 121.

47 In the 17th General Assembly, the Fifth Committee began consideration of the 1963 budget estimates on Oct. 4, 1962. For an example of adoption on the first reading of a section of the budget, see U.N. GeN. Ass. OfF. Rec. 17th Sess., 5th Comm. (A/C.5/SR.918) (provisional) (1962).

48 The second reading of the 1963 estimates in the Fifth Committee of the 17th General Assembly was in the 980th and 981st meetings, Dec. 18, 1962. See U.N. GEN. Ass. OFF. REc. 17th Sess., 5th Comm. (A/C.5/SR.980-981) (provisional) (1962). 


\section{4, which reads:}

No resolution involving expenditure shall be recommended by a committee for approval by the General Assembly unless it is accompanied by an estimate of expenditures prepared by the Secretary-General. No resolution in respect of which expenditures are anticipated by the Secretary-General shall be voted by the General Assembly until the Administrative and Budgetary Committee has had an opportunity of stating the effect of the proposal upon the budget estimates of the United Nations.

The principle of this rule is applied to other U.N. bodies by the financial regulations ${ }^{49}$ and similar rules of the Economic and Social Council, ${ }^{50}$ its commissions, ${ }^{51}$ and the Trusteeship Council ${ }^{52}$ but the Security Council has not imposed such a restriction upon itself. It is still an open question whether the General Assembly or any of its subsidiary organs could (or should) under the charter have any budgetary control over decisions of the Security Council. ${ }^{53}$

In the General Assembly practice, the Fifth Committee does furnish estimates or statements on the budgetary effect of proposals. These are drafted after receiving Secretariat and $A C A B Q$ recommendations, which

49 U.N. Fin. Reg. Nos. 13.1-.2. The text of these regulations is as follows:

Reg. 13.1: No council, counmission or other counpetent body shall take a decision involving expenditure unless it has before it a report from the Secretary-General on the administrative and financial implications of the proposal.

Reg. 13.2: Where, in the opinion of the Secretary-General, the proposed expenditure cannot be made from the existing appropriations, it shall not be incurred until the General Assembly has made the necessary appropriations, unless the SecretaryGeneral certifies that provision can be made under the conditions of the resolution of the General Assembly relating to unforeseen and extraordinary expenses.

50 U.N. Economic and Social Council Rules of Procedure [hereinafter cited as E.S.C. Rules], Rule No. 34, para. 2, U.N. Doc. No. E/3063 (1958).

${ }^{51}$ See Note by the Secretary-General, supra note 23, at 14-15.

52 Trusteeship Council Rules of Procedure, Rule No. 65, U.N. Doc. No. T/1/REV.6 (1962). See Note by the Secretary-General, Budgetary and Financial Practices of the U.N., supra note 23 , at 15 .

53 If the General Assembly were given power to deny funds necessary to carry out Security Council decisions, it could in a sense be said to have a veto over those Security Council decisions that depend upon regular U.N. financing. An alternative for the Security Council exists, however, under agreements entered into pursuant to article 43 of the U.N. Charter (no such agreements presently exist) and possibly under the implications of other charter articles. See, e.g., U.N. CHARTER art. 49: "The Members of the U.N. shall join in affording inutual assistance in carrying out the measures decided upon by the Security Council." 'The possibility of such a conflict between the General Assembly and the Security Council was discussed in connection with prehimmary drafts of the U.N. Charter. See RUSSELI \& MUTHER, op. cit. supra note 4, at 378. It is interesting to note that the basic decisions for ONUC were made by the Security Council. See U.N. Security Council Res. S/4387 (873d meeting) (1960); S/4405 (879th meeting) (1960) ; S/4426 (886th meeting) (1960); S/4741 (942d meeting) (1961); S/5002 (982d meeting) (1961). Cf. U.N. Gen. Ass. Res. Nos. 1474 (ES-IV) (1960); 1599 (XV) (1961); 1600 (XV) (1961); 1601 (XV) (1961). The financing was provided by the General Assembly. Decisions of the Security Council can be financed up to $\$ 10$ million under the "unforeseen and extraordinary" expense clause of the Working Capital Fund resolution. See note 43 supra and 
are usually accepted. ${ }^{54}$ This is scarcely an effective budgetary control feature, however, because the General Assembly or other bodies can and do pass measures despite cost estimates. The Fifth Committee, it has been said, is constantly being confronted with a fait accompli as the result of decisions of policy making organs of the U.N. which have financial impact over which the Fifth Committee has no control..$^{55}$ Concern about this problem lead the Fifth Committee to recommend and the General Assembly to adopt, on December 11, 1962, a resolution calling for the Economic and Social Council to devise a framework for greater budgetary control in U.N. programs in the economic, social, and human rights fields. ${ }^{56}$

accompanying text. The Secretary-General has commented on the contingency of a failure of the General Assembly to provide funds for a Security Council action, as follows:

The Secretary-General is neither entitled nor able to carry out political decisions for which funds have been refused. Conversely, he is not entitled to stop a political operation he has been ordered to carry out by the Security Council. Thus, there would remain nothing for him to do but to report the situation to the Security Council. Thereafter, the Council would urgently have to consider whether it would reverse its stand and take a decision to the effect that, because of the financial decision of the General Assembly, the Congo operation should be stopped. Were the Council to find that it could not take such a decision in view of its responsibilities and in view also of the recent substantive decisions of the General Assembly itself, it would, all the same, be impossible to carry out the Security Council and General Assembly decisions uuless, in some way, through an appropriate initiative the necessary means were to be made available.

4. How could the continued impossibility to carry out sucls decisions, required for peace and security, be justified by anyone who cares for the dignity of this Organization as it reflects on all its Member nations or, in fact be reconciled with the responsibilities of this Organization as laid down in the Charter?

U.N. Gex. Ass. OFF. Rec. 15th Sess., Annexes, Agenda Item No. 49/50, at 38 (A/C.5/867) (1961).

54 See, e.g., Advisory Services in the Field of Human Rights, Financial Implications of the Draft Resolutions Submitted by the Third Committee in document A/5277, U.N. GeN. Ass. OFr. Rec. 17th Sess., Annexes, Agenda Item No. 80 (A/C.5/L.750) (Nov. 21, 1962). In considering this report, the Fifth Committee had before it a report of the Secretary-General, U.N. Gex. Ass. Ofr. Rec. 17th Sess., Annexes, Agenda Item No. 80 (A/C.5/941) (1962), and a related report of the ACABQ, U.N. Gev. Ass. OFr. REc. 17th Sess., Annexes, Agenda Item No. 80 (A/5302) (1962); see U.N. GeN. Ass. OFF. Rec. 17th Sess., 5th Comm. (A/C.5/SR.954) (provisional) (1962).

55 U.N. GEN. Ass. OFr. Rec. 17th Sess., 5th Comm. 3 (A/C.5/SR.949) (provisional) (Nov. $19,1962)$.

56 The General Assembly ... Requests the Economic and Social Council: (a) To devise a framework within which the council can indicate the priorities to be accorded to United Nations programmes and projects in the economic, social and human rights fields, bearing in mind the objectives of the United Nations Development Decade; $(b)$ To establish within this framework an order of priorities for activities to be included in the work programme; $(c)$ To review regularly priorities in the hight of any unore recent or more urgent needs and the resources likely to be available to meet them; (d) To give due, timely and adequate consideration, as the work of the Council proceeds, to the financial implications of its actions in the hight of information provided to it by the Secretary-General; $(e)$ To consider, in connexion with sub-paragraphs $(a),(b),(c)$, and $(d)$ above, any comments of the Advisory Committee on Administrative and Budgetary Questions concerning the administrative and financial aspects of activities in the economic, social and human rights fields.

U.N. Gen. Ass. Res. No. 1797 (XVII) (1962). 
A brief examination of how the 1963 budget estimates fared in the seventeenth General Assembly (Fall 1962) will illustrate concretely the budget process and its operation. The Secretary-General's Budget Estimates for 1963 were presented in June 1962 in a 160 page document. ${ }^{57}$ His expenditure estimates totalled $\$ 86,649,500 .{ }^{58}$ These estimates, however, did not include added expenditure items expected to be placed in the budget for salary increases, U.N. bond interest and principal repayment, capital improvements for the headquarters building (needed because of additional members), and revised estimates resulting from Economic and Social Council decisions. ${ }^{59}$

The ACABQ met to review these estimates from June 5 to July 10 , 1962 , and recommended an overall decrease in the estimates of $\$ 1,966,050$. It did not, however, examine most of the sections involving technical and economic aid programs or bond expenses, not yet estimated. ${ }^{60}$

The 1963 budget figures adopted on first reading were in every case those recommended by the $\mathrm{ACABQ}{ }^{61}$ The final budgetary amounts were the ACABQ figures as revised by further recommendations of the ACABQ due to decisions of other U.N. bodies. ${ }^{62}$ Thus on the second reading of the

67 U.N. GeN. Ass. OFF. REc. 17th Sess., Supp. No. 5 (A/5205) (1962).

58 Over $80 \%$ of this figure was for staff costs and costs for buildings, equipment, and common services. Id. at v. The U.N. Director of General Services, Mr. Vaughn, indicated to the Fifth Committee on Nov. 7, 1962, that the detailed building expansion proposals were based on the assumption that membership of the UN. would increase to 126 during the next few years. U.N. Gen. Ass. OFF. REc. 17th Sess., 5th Comm. 13 (A/C.5/SR.941) (provisional) (1962).

59 Note 57 supra, at v.

$60 \mathrm{ACABQ}$, Seventh Report to the General Assembly at its Seventeenth Session, U.N. Gerr. Ass. OfF. Rec. 17th Sess., Supp. No. 7, at 11-12 (A/5207) (1962).

61 The budget estimates for 1963 can best be traced through the 17th General Assembly session with the use of the following documents: Budget Estimates for the Financial Year 1963 and Information Annexes, U.N. GeN. Ass. OFF. REc. 17th Sess., Supp. No. 5 (A/5205) (1962); ACABQ, Seventh Report to the General Assembly at its Seventeenth Session, supra note 60; Budget Estinates for the Fintancial Year 1963: Report of the Fifth Committee, U.N. GEN. Ass. OFF. REc. 17th Sess., Annexes, Agenda Item No. 62 (A/5391) (Dec. 19, 1962); Note by the Secretary-General, Budget Estimates for the Financial Year 1963, U.N. GeN. Ass. OfF. REc. 17th Sess., Annexes, Agenda Item No. 62 (A/C.5/967) (Dec. 17, 1962); U.N. Gen. Ass. OfF. REC. 17th Sess., 5th Comm. (A/C.5/SR.917-949) (provisional) (1962) (meetings of the Fifth Committee involving discussion and votes on budget sections on first reading); U.N. GEN. Ass. OFF. REc. 17th Sess., 5th Comm. (A/C.5/SR.980-981) (provisional) (1962) (meetings of the Fifth Committee at which votes were taken on the second reading).

62 U.N. Gen. Ass. Res. No. 1861 (XVII) (Dec. 26, 1962). An example of ACABQ action is the reduction in $\$ 4$, "common staff" costs (allowances, social security, pension costs, relocation costs), from $\$ 10,367,500$ to $\$ 10,039,500-a$ decrease of $\$ 328,000$. ACABQ Report, supra note 60 , at 11 . The ACABQ justified the reduction on the basis of new travel regulations, a more conservative forecast of separation payment needs, and reduced spending for "junior professional trainees." Id. at 26. By the time this natter was discussed in the Fifth Committee, estimates resulting from decisious of the Economic and Social Council had been received. U.N. 
twenty-one budget sections in the Fifth Committee, six were adopted unanimously, and all but four without negative votes (only abstentions). The closest vote on either first or second reading ( 57 in favor, 12 against, 5 abstentions) was on section 12 , special expenses, which included the U.N. bond amortization..$^{13}$ This indicates a remarkable record for ACABQ recommendations, which is partly explained by the fact that many delegates to the U.N. have instructions from their government to vote for ACABQ recommendations. Occasionally, however, ACABQ recommendations are not followed, as will be illustrated below. In addition it must be realized how limited $A C A B Q$ authority is, at least under its own interpretations. It will recommend on the question of cost of various items, once an activity has been decided upon, but has not deemed it appropriate to recommend on "policy matters" which involve questions such as whether or not a particular activity should be undertaken. ${ }^{64}$

The ultimate budget for 1963, as adopted, provides for a total expenditure (mcluding bond amortization) of $\$ 93,911,050$. Deducting income estimates and several other items, the net amount assessed to members for 1963 is about $\$ 85$ million. The U.S. share at 32.02 per cent would be about $\$ 28$ million. ${ }^{65}$

\section{B. Authorization and Control of Spending}

Regulation 4.1 of the U.N. financial regulations provides: "The appropriations voted by the General Assembly shall constitute an authorization to the Secretary-General to incur obligations and make payments for the purposes for which the appropriations were voted and up to the amounts as voted." The General Fund or annual regular budget is provided by the annual budget resolution which states, "Appropriations ... are hereby voted for the following purposes. ..." and then lists the twenty-one ex-

Gen. Ass. OFr. REc. 17th Sess., 5th Comm. (A/C.5/919) (1962). These estimates brought the Secretary-General's original figures for $\$ 4$ to $\$ 10,434,900$ and the $A C A B Q$ recommended amount to $\$ 10,089,500$. U.N. GeN. Ass. OFF. Rec. 17th Sess., 5th Comm. 7 (A/C.5/SR.938) (provisional) (Nov. 2, 1962). This ACABQ figure was approved on "first reading" of the committee. In two later meetings the Fifth Committee approved increases. At the 941 st meeting, revised salary scales for certain workers resulted in an addition to the estimate of $\$ 98,500$. At the 978th meeting, the Fifth Committee approved ACABQ estimates of an added $\$ 4,500$ for $\$ 4$, provided a Sixth Committee draft resolution providing for a juridical yearbook were adopted. This yearbook was approved, so the increase was added to $\$ 4$, bringing the total to $\$ 10,192,500$. This amount was subsequently approved by the committee on second reading. The General Assembly, when it adopted the recoinmended budget resolution, approved $\$ 10,195,500$, which included an added increase for a revised estimate. U.N. Gen. Ass. Res. No. 1861 (XVII) (1962). ${ }^{63}$ U.N. Gen. Ass. OFF. Rec. 17th Sess., 5th Comm. 3 (A/C.5/SR.981) (provisional) (1962). 64 ACABQ Report, supra note 60, at 4-5.

65 U.N. Gen. Ass. Res. No. 1861 (XVII) (1962). 
penditure sections of the budget. ${ }^{66}$ This establishes the basic authority for most of the usual U.N. spending. ${ }^{67}$

In addition, the financial regulations provide that obligations incurred during the financial year of the appropriation can be discharged for twelve months after the end of the appropriation year; thereafter, the balance remaining is surrendered. ${ }^{68}$ Under present practice, this remaining balance is used to reduce assessments needed for later appropriations. ${ }^{69}$

Financial regulation 10.1 commands the Secretary-General to establish internal financial controls. This is accomplished, first, by requiring written authorization of the Controller for all obligations on expenditures, which are usually in the form of allotments or authorization for employment of staff or consultants; and secondly, by various other controls, such as "manning tables" giving staff authorizations. ${ }^{70}$ Finally, the regulations provide for an external audit by a Board of Auditors which presents an annual report. ${ }^{71}$

This is the basic outline of the expenditure control and budget authorization of the regular U.N. budget. Many variations exist, however. For example:

(1) The Secretary-General has authority to transfer credits among budget sections with the prior concurrence of the ACABQ. ${ }^{72}$

(2) The Secretary-General may submit to the General Assembly supplemental requests when necessary, which the $A C A B Q$ must review and report upon..$^{73}$

(3) There is other fiscal transfer authority between small accounts for special purposes. ${ }^{74}$

(4) The annual authorization concerning unforeseen and extraordinary

66 Ibid. The sections of the budget are as follows: (1) travel and other expenses of representatives; (2) special meetings and conferences; (3) salaries and wages; (4) common staff costs; (5) travel of staff; (6) payments under annex $I$, paragraphs 2 and 3 , of the staff regulations, hospitality; (7) buildings and improvements to premises; (8) permanent equipment; (9) maintenance, operation, and rental of premises; (10) general expenses; (11) printing; (12) special expenses; (13) economic development; (14) social activities; (15) human rights activities; (16) public administration; (17) narcotic drugs control; (18) special missions; (19) U.N. field services; (20) office of the U.N. High Commissioner for Refugees; (21) International Court of Justice. Id. at 1-3.

67 UNEF and ONUC expenditures are separately provided. See notes 28 \& 29 supra.

68 U.N. Fin. Reg. Nos. 4.3-.4.

69 U.N. Gen. Ass. Res. No. 1861, pt. C, para. 1(b) (XVII) (1962).

70 U.N. Fim. Rules No. 110.1.

71 U.N. Fin. Reg. Nos. 12.1-.5; see, e.g., Financial Report and Accounts for the Year Ended 31 December 1961 and Report of the Board of Auditors, U.N. GEN. Ass. OFF. Rec. 17th Sess., Supp. No. 6 (A/5206) (1962).

72 See text accompanying note 42 supra.

73 U.N. Fin. Reg. Nos. 3.8-.9.

74 See U.N. Gen. Ass. Res. No. 1861, paras. 3, 4 (XVII) (1962). 
expenses allows the Secretary-General, with prior ACABQ concurrence, to spend necessary sums for unforeseen and extraordinary purposes, e.g., a Security Council decision involving troops. Certain types of these expenditures may be incurred without ACABQ approval, including sums up to $\$ 2$ million that the Secretary-General "certifies relate to the maintenance of peace and security."75

(5) There are a number of trust funds, reserve funds, and special accounts which may have their own financial rules and regulations or be administered under the general financial rules and regulations. ${ }^{70}$

(6) The Congo (ONUC) and Middle East (UNEF) accounts operate on continuing authorizations of inonthly rates of expenditure. ${ }^{77}$

These many exceptions soften the control that the budget process provides for U.N. finances, but in some cases at least they are necessary in order that U.N. organs can effectively act in a time of crisis. For instance, U.N. activity in Lebanon in the suminer of 1958 engendered a supplementary appropriation for that year of $\$ 3.7$ inillion for a U.N. Observation Group in Lebanon, in addition to supplementary appropriations for the special General Asseinbly meeting. ${ }^{78}$

The "unforeseen and extraordinary" expense authorization can be abused. The ACABQ expressed concern over such a possibility in its most recent report to the General Assembly, noting that supplementary appropriation for the 1962 budget would total over $\$ 2.8$ million (eventually to be $\$ 3,673,480)$. $^{79}$ One example of a supplemental appropriation made to finance expenditures under the "unforeseen" authority provides an interesting case study of the relationship of the ACABQ to the General Assembly, and the temper of General Assembly fiscal attitudes. This is the case of expenditures for Burundi and Rwanda.

As the trust territory Ruanda-Urundi neared independence from the

75 See note 43 supra.

76 See Note by the Secretary-General, Budgetary and Financial Practices of the U.N., supra note 23, at 33. U.N. Gen. Ass. Res. No. 1729 (XVI) (1961), establishes procedures for pledging conferences for the refugee programs, special fund, and the expanded program of technical assistance. For example, on Nov. 27, 1962, the General Assembly lield a conference for pledges of contributions to the programs of the High Commissioner for Refugees. See U.N. Jourrat No. 3034 (Nov. 27, 1962).

77 The latest UNEF authorizing resolution is U.N. Gen. Ass. Res. No. 1864 (XVII) (Dee. 20, 1962), which authorizes the Secretary-General to spend, through June 30, 1963, at an average monthly rate not to exceed $\$ 1,580,000$. Prior UNEF authorizing resolutions include the following: No. 1089 (XI) (1956); No. 1151 (XII) (1957); No. 1337 (XIII) (1958); No. 1441 (XIV) (1959); No. 1575 (XV) (1960); No. 1733 (XVI) (1961). The latest ONUC authorizing resolution is U.N. Gen. Ass. Res. No. 1865 (XVII) (Dec. 20, 1962), autliorizing the SecretaryGeneral to spend, through June 30,1963, at an average monthly rate not to exceed \$10 million. Former ONUC financing resolutions include No. 1583 (XV) (1960); No. 1590 (XV) (1960); No. 1595 (XV) (1960); No. 1619 (XV) (1960); No. 1633 (XVI) (1961); No. 1732 (XVI) (1961). See notes 166-70 infra and accompanying text.

78 U.N. Gen. Ass. Res. No. 1334 (XIII) (1958).

79 ACABQ Report, supra note 60, at 3-4. 
Belgian Administrating Authority in 1962, there was widespread concern that another "Congo" situation would develop. ${ }^{80}$ At its sixteenth session the General Assembly considered the problem and authorized the reconvening of the General Assembly on this matter. ${ }^{81}$ A resumed session of the sixteenth General Assembly was held from June 7 to 28, 1962, during which the General Assembly passed a resolution terminating the trusteeship and authorizing the emergence of two separate states-Rwanda and Burundi. This resolution requested the Secretary-General to study the need for technical and economic assistance in these new countries and report thereon, and authorized him:

... in accordance with the provisions of paragraph 1 of General Assembly resolution 1735 (XVI) of 20 December 1961 on unforeseen and extraordinary expenses for the financial year 1962, to enter into commitments not exceeding $\$ 2$ million for the purpose of such emergency measures as may be required to ensure the continuation of essential services in the two countries, pending the consideration by the General Assembly of the report of the Secretary-General . . . .82

In fact, the damage to public order in the new States that was anticipated as a possibility did not occur. No U.N. military mission to Rwanda or Burundi was needed. The Secretary-General asked, during the summer, for an appropriation of $\$ 800,000$ under the June resolution, for the repair of a road and construction of public housing. The ACABQ, however, recommended only $\$ 250,000$ of this amount. It was worried, first, that this type of expense was stretcling the definition of "unforeseen and extraordinary"; and, secondly, that this type of capital economic assistance did not belong in the regular U.N. budget. $^{83}$

The Fifth Committee considered the matter in meetings on October 30 and November 1, 1962. After considerable debate and some discussion of the legal points, the committee voted to increase the supplemental appropriation to $\$ 800,000$. The action was taken after a motion to adjourn debate was defeated, and a motion to end debate was adopted upon a close vote (21 to 20 , with 34 abstentions). The vote on the resolution was 50 in favor (primarily the African and Asian countries) to none against, with 37 abstentions (primarily Western and Communist countries). Because of the cloture motion, many delegates had no time to seek instructions from their governments before the action. ${ }^{84}$

80 Hearings on S. 2768 Before the House Committee on Foreign Affairs, 87th Cong., $2 \mathrm{~d}$ Sess. 28 (1962) (testimony of Ambassador Stevenson, June 27, 1962).

81 U.N. Gen. Ass. Res. Nos. 1743, 1744 (XVI) (1962).

82 U.N. Gen. Ass. Res. No. 1746 (XVI) (June 27, 1962).

83 U.N. GEN. Ass. OFF. REC. 17th Sess., 5th Comm. 9 (A/C.5/SR.934) (provisional) (Oct. $30,1962)$.

84 U.N. Ger. Ass. OfF. REc. 17th Sess., 5th Comm. (A/C.5/SR.937) (provisional) (Nov. 1, 1962). 
Immediately after the vote was announced the question arose of what would happen to the unexpended balance of the $\$ 800,000$ at the end of 1962. Here again there was a wide divergence of opinion, with some delegates warning of the dangerous precedent of carrying over the funds, and others arguing that the intent of the resolution was to do just that. ${ }^{85}$ The end result was to include in the supplemental appropriation resolution a paragraph which read:

... the unexpended balance of the 1962 appropriation of $\$ 800,000$ in respect of emergency measures for the maintenance of essential services in Burundi and Rwanda ... shall be transferred on 31 December 1962 to a trust fund account for meeting expenditures for these two projects authorized by the General Assembly in resolution 1746 (XVI) . . . ${ }^{86}$

The final resolution passed the General Assembly, of course, since no member wanted to reopen the question at that late stage.

The net result of this affair was that an expenditure was approved: (1) on a vote of less than half the membership; (2) that stretches the interpretation of "unforeseen and extraordinary," thus posing a danger of future misuse of this provision to dilute necessary budgeting and fiscal responsibility of the U.N.; (3) which in effect provides funds which will be obligated and spent in 1963, but will not appear in the 1963 budget accounts; (4) that disregarded an ACABQ recommendation.

It is hard to escape the conclusion that this proceeding was irresponsible, and could pose serious precedential consequences for the future. This is true, particularly, since the combined percentage of assessments of all States that voted for the measure totalled less than 16 per cent.

Moreover, the ambivalent attitude of the ACABQ itself cannot be overlooked. If it truly had doubts about the legality of the appropriation, it would perhaps have been better logic not to recommend a supplemental appropriation under the authority of the "unforeseen" rule, but instead to have recommended a supplementary appropriation with new General Assembly authorization for 1962 and a separate appropriation for 1963 . However, the necessity of compromise involved in the very essence of political processes must be recognized.

Some tentative conclusions can be drawn from the discussion so far. In practice, as well as in theory, the General Assembly is the spending authority of the U.N., and the equal voting principle there gives small contributors as much power as large. The ACABQ does furnish some measure of increased influence for the larger contributors who are represented on it, but there is reason to doubt that $\mathrm{ACABQ}$ authority, as presently constituted, is sufficient to furnish a sound degree of financial responsibility for 
the U.N., or to give realistic weight to the differences in contributions from members, if that be a desideratum.

This discussion, of course, has not purported to give more than a sideways glance at the growing, complex, and important economic and technical aid spending through the U.N. ${ }^{87}$

\section{III}

\section{U.N. FINANCIAI SOURCES}

United Nations funds originate primarily from four basic sources: assessments, borrowing, mcome from various activities and staff assessment, and voluntary contributions.

\section{A. Assessments}

The three major funds of the U.N., and the ones that bear most vitally on the important question of peacekeeping activities, are, as mentioned above, the General Fund, the Ad Hoc Account for ONUC (Congo), and the Special Account for UNEF (Suez).$^{88}$ These three funds, plus the Working Capital Fund, are the only U.N. accounts presently financed by assessment of members. How does the assessment process operate? Upon what bases is the percentage each country must pay computed?

The basic authority for assessing members is in article 17 of the charter. The General Assembly, at its first session in 1945, established a Committee on Contributions. ${ }^{89}$ Under present General Assembly rules, the committee is an appointed "expert Committee on Contributions, consisting of ten members," no two from the same State.90

The committee is charged with advising the General Assembly "concerning the apportionment, under Article 17, paragraph 2, of the Charter, of the expenses of the Organization among Members, broadly according

\footnotetext{
87 See generally Note by the Secretary-General, Budgetary and Financial Practices of the U.N., supra note 23 .

88 See notes $27-29$ supra.

89 U.N. Gen. Ass. Res. No. 14A3, para. 3 (I) (1946).

90 Gen. Ass. Rules Nos. 159, 160. The composition of the Committee on Contributions for 1962 was as follows: Chairman: H.E. Mr.C.S. Jha (India); Members: Mr. Raymond T. Bowman (U.S.A.), Mr. P. Chernyshev (U.S.S.R.), Mr. C. H. W. Hodges (United Kingdom), Mr. F. Nouredin Kia (Iran), Dr. Jose Pareja y Paz Soldan (Peru), Mr. Sidney Pollock (Canada), Mr. Stanislaw Raczkowski (Poland), Mr. Maurice Viaud (France). Permanent Missions to the United Nations, U.N. Doc. No. ST/SG/SER.A/149 (1962). During the 17th session of the General Assembly, the following members were appointed to the Committee on Contributions: Mr. B.N. Chakravarty (India), Mr. T.W. Cutts (Australia), Mr. James Gibson (United Kingdom), and Mr. D. Silveira da Mota (Brazil). O.N. Gen. Ass. Res. Nos. 1792 (XVII) (Dec. 11, 1962); 1792A (XVII) (Dec. 19, 1962).
} 
to capacity to pay."91 The rules provide that a scale of assessments once fixed is not subject to general revision for at least three years, "unless it is clear that there have been substantial changes in relative capacities to pay."

The committee operates primarily under the mandate of four General Assembly resolutions. The first and original terms, from the first session of the General Assembly, ${ }^{33}$ provided for apportionment "broadly according to capacity to pay," based prima facie on comparative estimates of national income, tempered, however, by: (1) comparative income per capita of population; (2) temporary dislocation due to World War II; (3) ability to secure foreign currency; and (4) a policy against both unduly large and unduly small contributions.

Later resolutions added a mandatory "ceiling" or maximum percentage, and the "per capita ceiling" principle. ${ }^{94}$ The ceiling principle, which will be discussed at greater length in the next part concerning U.S. contributions to the U.N., presently provides that no member will be assessed more than $33 \frac{1}{3}$ per cent, ${ }^{95}$ and that "in principle" no member shall be assessed more than 30 per cent. ${ }^{96}$ The per capita ceiling principle provides that the per capita contribution of any member shall not exceed the per capita contribution of the member that bears the highest assessment.

Under these terms, the Committee on Contributions meets and draws up an assessment scale to be recommended to the General Assembly. Its last general revision was made in 1961, for the years 1962-1964. The appendix contains the details of the committee's calculations. The resulting scale was recommended to the sixteenth General Assembly (Fall 1961) where, expectedly, it encountered stiff opposition in the Fifth Committee from the Soviet delegation, because of increases in the U.S.S.R. percentage from 13.62 to $14.97{ }^{97}$ With the inclusion of a compromise provision that the Committee on Contributions should reconsider its work in 1962 for possible revision of the scale, instead of the usual wait of three years, the recommended scale was adopted. ${ }^{98}$ The committee did meet on this and other questions in the summer of 1962 , but recommended no change in the scale..$^{99}$

01 Gen. Ass. Rules No. 161.

Q2 Ibid.

93 U.N. Gen. Ass. Res. No. 14A3 (I) (1946).

94 U.N. Gen. Ass. Res. Nos. 238A (III) (1948); 665 (VII) (1952).

95 U.N. Gen. Ass. Res. No. 665 (VII) (1952).

96 U.N. Gen. Ass. Res. No. 1137 (XII) (1957).

97 Committee on Contributions, Report, U.N. GEN. Ass. OFF. REc. 16th Sess., Supp. No. 10 (A/4775) (1961). The current combined percentage for the U.S.S.R., Byelorussian S.S.R., and Ukrainian S.S.R. is $17.47 \%$, compared to a previous figure of $15.89 \%$.

98 U.N. Gen. Ass. OFF. REc. 16th Sess., 5th Comm. 201 (A/C.5/SR.869) (1961); U.N. Gen. Ass. Res. No. 1691, para. 5 (XVI) (1961).

99 U.N. Gen. Ass. OfF. Rec. 17th Sess., Supp. No. 10, at 2 (A/5210) (1962). 
A scale can be calculated a number of different ways, and on the basis of a variety of data. For instance, the adjustment which is presently made to reduce the percentage of countries with a low per capita national income $e^{100}$ could be changed with a wide variety of results. Surprisingly little public information or discussion exists on the question of fair ways to construct assessment scales of international organizations. With the growing importance of these organizations, and the great increases in their budgets, it would seem appropriate for economists and other students of public finance to apply their skills to the very puzzling questions involved in assessing member nations.

Perhaps the weakest link in the apportionment process, is the basic data on which the scale is based. This is recognized by the Committee on Contributions itself in its reports, ${ }^{101}$ and by the General Assembly, which in its latest resolution on the assessment scale requested the SecretaryGeneral to undertake an expert study comparing national accounting. ${ }^{102}$

The assessment scale, once adopted, is then applied by the appropriate financing resolution. For instance, for 1963, resolution 1861 (XVII) provides, in part, that $\$ 89,406,446$ of the budget is assessed on member States according to the assessment scale resolution previously adopted. Assessments for the ONUC and UNEF accounts, when they were made, are somewhat more complex. ${ }^{103}$

Under the financial rules and regulations, once the budget is adopted and assessed, the Secretary-General must inform the members of and request them to remit their assessments. ${ }^{104}$ The regulations then state:

Contributions and advances shall be considered as due and payable in full within thirty days of the receipt of the communication of the SecretaryGeneral ... or as of the first day of the financial year to which they relate, whichever is the later. As of 1 January of the following financial year, the unpaid balance of such contributions and advances shall be considered to be one year in arrears. ${ }^{105}$

In addition, "payments made by a Member State shall be credited first to the Working Capital Fund and then to the contributions due in the order in which the Member was assessed."106 This latter provision has apparently been consistently ignored in applying payments of States that refuse to pay peacekeeping assessments. Thus, although many are paid up in the U.N.

100 See appendix; Committee on Contributions, Report, supra note 97, at 3 .

101 Id. at 2, para. 11; A/5210, supra note 99, at 2, para. 9.

102 U.N. Gen. Ass. Res. No. 1870 (XVII) (Dec. 20, 1962).

103 See discussion in part V, following note 151 infra.

104 U.N. Fin. Reg. No. 5.3.

105 U.N. Fin. Reg. No. 5.4.

106 U.N. Fin. Reg. No. 5.6. 
General Fund, they may be in arrears to the UNEF accounts which date back to 1957 .

\section{B. The Working Capital Fund and Borrowing}

Because many countries do not remit assessments until later in the financial year, resort to a working capital fund is necessary to provide the cash needed until the assessments come im. ${ }^{107}$ The Working Capital Fund is essentially a revolving fund, presently set at $\$ 40$ million, ${ }^{108}$ supplied by advances from each member State in the proportion of the fund corresponding to its assessment percentage under the assessment scale. ${ }^{100}$ Advances from the fund are made to finance specific budgetary appropriations as needed, until such time as contributions (or other income) received enable the Working Capital Fund to be repaid. ${ }^{110}$ When advances are made for "unforeseen and extraordinary expenses," the Working Capital Fund is repaid by a supplemental appropriation passed at the next session of the General Assembly. ${ }^{111}$

Apart from this source, the Secretary-General has the following borrowing authority:

(1) When the Working Capital Fund is inadequate, the Working Capital Fund resolution authorizes the Secretary-General to utilize cash from "special funds and accounts in his custody," under certain conditions. ${ }^{112}$

107 See U.N. Fin. Reg. Nos, 6.2--.4.

108 U.N. Gen. Ass. Res. No. 1863 (XVII) (Dec. 20, 1962).

100 U.N. Gen. Ass. Res. No. 1863 (XVII) (1962) sets the working capital fund for 1963 at $\$ 40$ million, an increase over the $\$ 25$ million of the previous year. Each year a new fund is constituted. In effect, each member's proportional contribution is due, but is mostly offset by the nember's share of the previous year's fund which is credited to the new fund. Note by the Secretary-General, Budgetary and Financial Practices of the United Nations, U.N. Doc. No. A/AC.113/1, at 25 (1963).

110 U.N. Fin. Reg. No. 6.3; Note by the Secretary-General, sutpra note 109, at 26.

111 U.N. Fin. Reg. No. 6.4; Note by the Secretary-General, supra note 109, at 26.

112 U.N. Gen. Ass. Res. No. 1863 (XVII) (Dec. 20, 1962) reads in part:

5. Should the provision in paragraph 1 above prove inadequate to meet the purposes normally related to the Working Capital Fund, the Secretary-General is authorized to utilize, in 1963, cash from special funds and accounts in his custody, under the conditions approved in General Assembly resolution 1341 (XIII) of 13 December 1958, or the proceeds of loans authorized by the Assembly.

Resolution 134I (XIII) refers in turn to the conditions of paragraph 8 of the SecretaryGeneral's report, apparently referring to U.N. GEN. Ass. OFF. REc. 13th Sess., Annexes, Agenda Item Nos. 43-44, at 55 (A/C.5/743) (1958), which hists as conditions of such borrowing:

(a) that special accounts ... he drawn on only as a last resort; (b) that such funds ... be used only if they were not immediately required for the normal programmes for which they were designed and without prejudice to those programmes; (c) that repayment of any such advances ... be a first charge on contributions received.

U.N. Gen. Ass. Res. No. 1341 (XIII) (1958) provides for "payment of normal current rates of interest" for the loan so made. It is interesting that in the Working Capital Fund resolutions 
(2) The U.N. bond issue resolution authorizes borrowing of up to $\$ 200$ million from members of the U.N. and specialized agencies, and, with $A C A B Q$ concurrence, from nonprofit institutions. The Secretary-General is authorized to utilize these funds "for purposes normally related to the Working Capital Fund."113

(3) The separate UNEF financial regulations provide:

In addition to the advances from the United Nations Working Capital Fund . . . arrangements may be made where necessary for loans to the Special Account from other appropriate sources, including other funds under the custody or control of the Secretary-General. Any such loan shall require the personal approval of the Secretary-General.114

No provision for borrowing exists in the general financial rules or regulations. There are no separate financial rules or regulations for ONUC. ${ }^{118}$ In addition to the general authority that is listed above, occasionally the Secretary-General is given authority to borrow for specific projects, usually

prior to that for 1962, the Secretary-General was authorized, in addition to borrowing from funds in his custody, "to seek sbort-term loans from Governments." U.N. Gen. Ass. Res. Nos. 1586 (XV) (1960); 1448 (XIV) (1959). This authority was omitted from the resolutions for 1962 and 1963, presumably because the bond issue was authorized. Other borrowing authority has been suggested for the U.N. For instance, Senator Aiken urged that the U.N. be loaned money by the International Bank for Reconstruction and Development in lieu of a UN. bond issue. 108 CoNG. Rec. 10293-96 (daily ed. June 20, 1962). Although extensive borrowing by the U.N. is obviously a subject of much controversy, it would seem appropriate, at least for the purpose of providing funds that would otherwise be provided by unpaid assessments, if such borrowing were used to tide the United Nations over until the article 19 loss of vote sanction were apphed for such arrears. It might be even more appropriate to charge the country in arrears for the interest cost of such borrowing. See note 269 infrc and accompanying text.

113 U.N. Gen. Ass. Res. No. 1739 (XVI) (1961) ; see text accounpanying note 204 infra, regarding the use of these bond funds.

114 Secretary-General's Bulletin, Financial Rules for the Special Account for the United Nations Emergency Force, U.N. Doc. No. ST/SGB/UNEF/2/REV.2, at 2 (1960). The author is unaware of any single use of this authority to borrow from "other appropriate sources," although borrowing from other funds in the custody of the Secretary-General has occurred. Since UNEF arrears are so small in comparison with ONUC arrears, there bas been little need to utilize this power. In addition, since similar power was more recently taken away from the Secretary-General in his general borrowing authority, see note 112 supra, it is probably deemed inexpedient to try to utilize this power.

115 "The general financial policies and practices that are being applied in connexion with ONUC are in all important respects identical with those that are applicable to UNEF." Note by the Secretary-General, Budgetary and Financial Practices of the United Nations, supra note 109, at 91. "Pending the establisliment of . . . [special financial rules for the ONUC account], the concurrence of the Advisory Committee on Administrative and Budgetary Questions has been sought and obtained to establish arrangenents for liquidation of ONUC obligations identical with those approved for UNEF obligations in rule 103.3(b) of the UNEF Financial Rules." Ibid. There is, however, a set of "provisional financial rules of the United Nations Fund for the Congo," the fund which is supphed by voluntary contributions and used for "costs incurred for restoration of the economic life of the Congo and carrying on its public services ... ." U.N. Doc. No. ST/SGB/CONGO FUND/1, at 2 (1961). 
a capital improvement. For instance, the New York headquarters was built on a loan from the U.S.116

\section{Staff Assessment and Income From Activities}

The U.N. receives some income from the sale of postage stamps and publications, and from other activities. ${ }^{117}$ In addition, the budget lists an item of income (about $\$ 9$ million for 1963 ) $^{118}$ based on assessment of U.N. staff members under General Assembly resolutions. ${ }^{119}$ The financial rules allow refund of this assessment to the staff member up to the amount of tax a staff member must pay to a member nation in respect of his U.N. salary. ${ }^{120}$ Through a system of credits against member contributions, the U.N. provides, in effect, that any nation which taxes its nationals who are U.N. staff members pays for most of this tax itself through a higher ("less lower") contribution to the U.N. ${ }^{121}$ The United States is the only member

116 U.N. Gen. Ass. Res. No. 242 (III) (1948). The annual amortization of the headquarter's construction loan, which totalled $\$ 65$ million, is presently $\$ 2.5$ million. See Budget Estimates for the Financial Year 1963, U.N. Gen. Ass. OFr. Rec. 17th Sess., Supp. No. 5, at 64 (A/5205) (1962).

117 See U.N. Gen. Ass. Res. No. 1861, pt. B (XVII) (1962).

118 Ibid.

119 The latest is U.N. Gen. Ass. Res. No. 1658 (XVI) (1961), which amends staff regulation 3.3, paragraph $b$, to read as follows:

The assessment shall be calculated according to the following rates:

\section{Total assessable payments}

First $\$ 1,000$ per ycar

Next $\$ 2,000$ per year

Next $\$ 3,000$ per year

Next $\$ 3,000$ per year

Next $\$ 3,000$ per year

Next $\$ 3,000$ per year

Next $\$ 4,000$ per year

Next $\$ 4,000$ per ycar

Remaining assessable payments

\section{Assessment PerCent}

10

15

20

25

30

35

40

45

50

120 U.N. Fin. Rules No. 105.5 provides as follows:

Credits to member states shall be recorded in the accounts of the fund in the proportion of the contribution of each member state for the financial year concerned. Credit of a member state shall be utilized to reimburse staff members for national income taxes levied by that member state in respect of income derived from the organization, provided that where the total of such reimbursements is in excess of the member states credit in the fund, the excess shall be charged to the regular budget of the U.N.

Thus, as long as the tax equalization fund is large enough that the United States share of it, $32.02 \%$, is equal to or greater than the total federal and state income taxes levied on U.S. citizen employees of the U.N., the United States pays for this tax.

121 U.N. Fin. Rules Nos. 105.4-.7. See the description of the system in Budget Estinates for the Financial Year 1963, supra note 116, at 149. 
presently taxing its nationals on the U.N. staff. ${ }^{122}$

$D$. Voluntary Contributions to the U.N.

A great deal of the work that is carried out under U.N. auspices is funded from voluntary contributions of member states, often solicited by an annual pledging conference on extrabudgetary funds. ${ }^{123}$ Most of these funds are placed in a special account (e.g., the United Nations Fund for the Congo), or trust fund (e.g., United Nations Congo Famine Fund). ${ }^{124}$ The

122 Hearings on $S .2768$, supra note 80, at $371 \mathrm{n} .2$. Financial Report \& Accounts for the Year Ended 31 December 1961, U.N. Gen. Ass. OFf. REc. 17th Sess., Supp. No. 6, schedule 3, at $44(\mathrm{~A} / 5206)$ (1962), gives the status of the tax equalization fund as of that date. The only entries for member government taxes are for U.S. federal income tax and New York State income tax.

The necessity for the tax equalization measures of the U.N. stems from the following circumstances. The charter of the U.N. states generally tbat "the Organization shall enjoy in the territory of each of its Members such privileges and immunities as are necessary for the fulfillment of its purposes." U.N. CHARTER art. 105. This article also empowers the General Assembly to propose conventions to members to determime the details of such privileges and immunities. The General Assembly consequently, by U.N. Gen. Ass. Res. No. 22A (I) (1946), recommended for accession by members the Convention on the Privileges and Immunities of the U.N. Section 18 of this convention provides, in part, that officials of the UN. shall: "(b) be exempt from taxation on the salaries and emoluments paid to them by the U.N. . . ." Most of the members of the U.N. have acceded to this convention. See U.N. LegisLative SerIES, 1 Legislative Text and Treaty Provistons Concerning tene Legal Status, Prunileges, and IMMIUNITIES OF InTERNatIonaI ORganizations, U.N. Doc. No. ST/LEG/SER.B/10, at 190 (1959). The United States, however, has not ratified this convention and the privileges and immunities for international organizations in this country are governed by the International Organizations Imnunities Act of 1945, 59 Stat. 669, 22 U.S.C. $\$ 288$ (1958). By Exec. Order No. 9698, 11 Fed. Reg. 1809 (1946), the Umited Nations was designated as one of the international organizations entitled to enjoy the privileges, exemptions, and immunities conferred by this act. The act, however, does not exempt from taxation United States officials who are employees of international organizations. Therefore, without the tax equalization fund provisions of the U.N., the United States would, in effect, be taxing back a portion of its contribution to the United Nations, a privilege which other members of the U.N. have relinquished. Another effect of the absence of a tax equalization fund would be that different officials of the U.N. would be, in effect, paid differently, i.e., not on the basis of the work they do or the position they hold, but on the basis of their citizenship. See description of the Tax Equalization Fund in Hearings on Departments of State, Justice, and Commerce, the Judiciary, and Related Agencies Appropriations for 1963 Before a Subcommittee of the House Committee on Appropriations, 87th Cong., 2d Sess. 970-71 (1962).

123 See note 23 supra.

124 See Note by the Secretary-General, Budgetary \& Financial Practices of the U.N., supra note 109, at 33, which gives the following list of funds: Trust funds: (1) Library Endowment Fund; (2) The Dag Hammarskjold Library-gift of the Ford Foundation; (3) Congo Relief Counterpart Fund; (4) United Nations Congo Famime Fund; (5) United Nations Korean Reconstruction Agency-residual assets; (6) U.N. Suez Canal clearance operation; Reserve funds: (1) U.N. Joint Staff Pension Fund; (2) Pension fund for part-time employees in the European office of the U.N. in Geneva; Special accounts: (1) Special account for the expanded program of technical assistance; (2) U.N. participation in the expanded program of technical assistance; (3) Technical Assistance Board Secretariat; (4) U.N. Special Fund; (5) U.N. overhead costs for Special Fund projects; (6) U.N. as executing agency for Special Fund projects; (7) Admin- 
fund with the biggest potential, and largest present balance is the United Nations Special Fund, designed to be used for technical and economic aid for less developed countries. The investments on hand in this account at the end of 1961 totalled $\$ 71,392,378 .^{125}$

UNITED STATES CONTRIBUTIONS TO THE U.N.

As the largest single contributor, it is not surprising that the United States has had an immense impact on U.N. financing. When the U.N. was initially organized, a Committee on Contributions recommended in 1946 a scale of assessments based on 1938-1940 national income statistics which would have placed the U.S. at 49.89 per cent. Senator Vandenberg, a U.S. delegate, strongly argned that the data was wrong, and that no one country should contribute such a large percentage, because "such a large assessment to any one nation would ultinutely have an effect on the sovereign equality of nations." On reconsideration, the committee recommended and the General Assembly approved a scale with the U.S. assessment at 39.89 per cent. ${ }^{126}$ Subsequently this percentage was decreased until in 1952 the General Assembly established a general ceiling of $33 \mathrm{r} / 3$ per cent which became effective in 1954. ${ }^{122}$ In 1957 the General Assembly resolved that the ceiling should be gradually reduced to 30 per cent. ${ }^{128}$ In the current scale the U.S. pays 32.02 per cent. ${ }^{129}$

The questions of the U.S. share and the ceiling principle can be endlessly debated. Especially since the costly Suez and Congo operations arose, the ceiling principle has come under more attack. ${ }^{130}$ Without the ceiling, under current scale data (1957-1959 average national income), the U.S.

istrative budget of, and preparatory allocation to, the managing director of this special fund; (8) U.N. Relief and Works Agency for Palestine Refugees in the Near East (UNRWA);

(9) Voluntary funds administered by the U.N. High Commissioner for Refugees; (10) U.N. Childrens' Fund (UNICEF); (11) U.N. Fund for the Congo; (12) Special Account of the UN. Emergency Force (UNEF); (13) Ad Hoc Account for the U.N. Operations in the Congo (ONUC). See also Financial Report and Accounts for the Year Ended 31 December 1961, supra note 122.

125 Financial Report and Accounts for the Year Ended 31 December 1961, supra note 121, schedule 16, at 69 .

126 Singer, Financing International Organization: The United Natxons Budoet Process 125-27 (1961).

127 U.N. Gen. Ass. Res. No. 665 (VII) (1952).

128 U.N. Gen. Ass. Res. No. 1137 (XII) (1957).

129 U.N. Gen. Ass. Res. No. 1691 (XVI) (1961).

130 See U.S.S.R. Draft Resolution, U.N. GEN. Ass. OfF. REc., 17th Sess., Annexes, Agenda Item No. 65 (A/C.5/L.732) (1962), and discussion in the 5th Committee, UN. GeN. Ass. OfF. REc. 17th Sess., 5th Comm. (A/C.5/SR.975 978) (provisional) (Dec. 14-17, 1962). 
apparently has a national income that equals over 38 per cent of the total incomes of U.N. members. ${ }^{131}$

Ambassador Stevenson, testifying before the House Foreign Affairs Committee on the U.N. Bond Bill in June 1962, stated that statistics would indicate the U.S. should pay 44 to 45 per cent. ${ }^{132}$ The Soviet bloc delegates have been kind enough to use this statement against the U.S. in U.N. Fifth Committee discussions. ${ }^{133}$

In fact, the U.S. has limited itself to contributions of one-third of the budgets of the U.N. and most international organizations. The Departments of State, Justice, Commerce and the Judiciary Appropriations Act for fiscal 1953 (passed in 1952) contains the following provision:

No representative of the United States Government in any international organization after fiscal year 1953 shall make any commitment requiring the appropriation of funds for a contribution by the United States in excess of $33 \mathrm{r} / 3$ per centum of the budget of any international organization for which the appropriation for the United States contribution is contained in this Act .... ${ }^{134}$

Although it is not entirely clear, this provision was apparently intended to be permanent legislation. ${ }^{\mathbf{1 3 5}}$ At any rate, the annual joint House and Senate

131 Since the particular data used by the Committee on Contributions in formulating its recommended scale is not publicly available, it is not possible to calculate independently a percentage figure for the United States based upon that data. However, the Soviet delegate to the U.N. has stated this percentage for the United States several times in the Fifth Committee ostensibly quoting Ambassador Stevenson. See U.N. GeN. Ass. OfF. Rec. 17th Sess., 5th Comm. 6 (A/C.5/SR.922) (provisional) (1962). At the 975th meeting of the 5th Committee, on Dec. 14, 1962, Ambassador Klutznick of the United States referred to the U.S.S.R. assertion and did not negate or refute it. Mr. Klutznick stated that on the basis of the recognized great responsibilities of the United States alone, its contribution should be $40 \%$, but that in fact, including all the various voluntary contributions as well as assessments, the United States was contributing 47\%. U.N. GeN. Ass. OFF. REc. 17th Sess., 5th Comm. 15 (A/C.5/SR.975) (provisional) (1962).

132 Hearings on S. 2768 Before the House Committee on Foreign Afairs, 87th Cong., $2 \mathrm{~d}$ Sess. 35 (1962). This percentage probably is based upon weighted national income statistics, after adjustments are inade for various reasons. See appendix.

133 See U.N. GEN. Ass. OFF. REc. 17th Sess., 5th Comm. 4 (A/C.5/SR.929) (provisional) (Oct. 23, 1962), where Mr. Komives (Hungary) quoted Mr. Stevenson's testimony before the House Committee on Foreign Affairs. This is an illustration of how the United States Department of State is often whipsawed between the arguments which it must make to obtain necessary action in Congress, and the arguments which it must make im the United Nations.

13466 Stat. 550 (1952).

135 In the appropriation act for the Departments of State, Justice, Commerce, and the Judiciary for the fiscal year ending June 30 , 1952, Congress included a clause worded almost identically to that reproduced in the text from the fiscal year 1953 act. The fiscal 1952 act, however, contained a proviso that read as follows:

Provided, That in exceptional circumstances necessitating a contribution by the United States in excess of $331 / 3$ per centum of the budget, a commitment requiring a Umited States appropriation of a larger proportion may be made after consultation by United States representatives in the organization or other appropriate 
committee print, Legislation on Foreign Relations, includes it. ${ }^{136} \mathrm{~A}$ similar one-third limitation was passed the prior year (1951, for fiscal 1952), but with a clause allowing higher contributions in "exceptional circumstances."137 After this legislation and the 1952 General Assembly ceiling resolution, the U.S. assessed contribution for 1954 was, for the first time, lowered to $33 \mathrm{~T} / 3$ per cent. ${ }^{138}$

One source of minor discontent to other U.N. members is the U.S. method of paying the U.N. The U.S. usually provides for the current U.N. financial year (calendar year) contribution in its appropriations for the U.S. fiscal year that begins in mid-U.N. year. United States contributions to the U.N. are, therefore, generally paid in July. ${ }^{138}$ This allegedly necessitates heavy U.N. drawing on the Working Capital Fund, and consequently a larger fund than might otherwise be necessary. ${ }^{140}$

One must not forget, however, that U.S. assessed contributions are not the extent of its financial participation in the U.N. The U.S. makes very substantial "voluntary" contributions, in addition to its assessments. In

officials of the Department of State with the Committees on Appropriations of the

Senate and House of Representatives .... .

65 Stat. 599 (1951). There is evidence in the legislative history that this provision of the fiscal 1952 act was intended to be permanent legislation to apply to future appropriation bills. See 97 CoNG. REc. 7871, 8682, 8885, 8887, 8980, 8981, 8988, 12989, 13084 (1951), especially a statement by Mr. Williams of Mississippi in the House, as follows: "In my opinion, what this language says is that we shall limit our contribution to these organizations hereafter-not applying to this particular bill, but to future appropriation bills . . ." 97 Conc. Rec. 12989 (1951).

The House Committee on the Judiciary, the codifiers of Title 22 of the Uniled States Code, apparently regarded the clause as permanent legislation, for it was and is included as 22 U.S.C. \$ 262b (1958). This text also appears in 22 U.S.C.A. \$ 262b (Supp. 1962) as pubhished by the West Publishing Co. However, the same section in the Federal Code Annotated (1958), compiled and published by the Bobbs-Merrill Co., contains the language of the fiscal year 1953 act, omitting the proviso. In addition, the similar appropriation act for fiscal year 1954 included an ainendment to 22 U.S.C. \& $262 \mathrm{~b}$, without any reference to the fiscal year 1953 act. See 67 Stat. 368 (1953).

There is evidence that the fiscal year 1953 act was also intended to be permanent legislation. See 98 Cong. REc. 3517, 8099, 9443, 9444 (1952).

The author expresses appreciation to C. Graham Tebbe, Jr., a third year law student at the University of California School of Law, Berkeley, for his able research assistance on the matters in this footnote.

136 Senate Comm. on Foreign Relations \& House Comm. on Foreign Afrairs, 87th Cong., 2D Sess., Legislation on Foreign Relations 343 (Comm. Print 1962).

137 See note 135 supro.

138 U.N. Gen. Ass. Res. No. 665 (VII) (1952).

139 See U.N. Doc. No. ST/ADM/Ser.B/162, at 2 (Aug. 1, 1962); Departments of State, Justice, and Commerce, the Judiciary, and Related Agencies Appropriations Act, 1963, 76 Stat. 1080 (1962). To provide for quicker payment, the United States would have to estimate the probable assessment about a year before it is set by the General Assembly, and apply to Congress for part or all of that estimate in the preceding appropriation bill.

140 U.N. GEN. AsS. OFF. REC. 17th Sess., 5th Comm. 8 (A/C.5/SR.970) (provisional) (Dec. 11, 1962). Some nations pay by installments. Allegedly the U.S.S.R. quite often has not paid until December. 
the U.S. Congress a sharp distinction is made between the assessed contributions which are obligations of the U.S. pursuant to "treaties, conventions or specific Acts of Congress," and voluntary contributions. The former are authorized by separate acts and appropriated under the Departments of State, Justice, and Commerce, the Judiciary, and Related Agencies Appropriations Act. ${ }^{141}$ Voluntary contributions, however, are generally authorized by section 302 of the Foreign Assistance Act of 1961, ${ }^{142}$ and appropriated in the Foreign Aid and Related Agencies Appropriation Act. ${ }^{143}$ Different subcommittees of the House Appropriations Committee handle each type of contribution, ${ }^{144}$ although each is clearly aware of what the other is doing. ${ }^{145}$ Both types of funds are funnelled through the same office in the Department of State for transmittal to the Organization. ${ }^{148}$

For this reason limitations on U.S. contributions to U.N. programs may differ. For instance, under section 301(b) of The Foreign Assistance Act of 1961, U.S. contributions (voluntary) to the United Nations Expanded Program of Technical Assistance and the United Nations Special Fund are limited to 40 per cent. ${ }^{147}$ There is no expressed percentage limitation on other types of U.S. voluntary contributions to the U.N. The U.S. can and does, therefore, contribute more heavily to some other U.N. activities, in particular, the UNEF or ONUC operations. ${ }^{148}$ The extent of U.S. vol-

141 For the U.N. see, e.g., United Nations Participation Act $\$ 8$, 59 Stat. 621 (1945), as amended, 22 U.S.C. $\$ 287$ e (Supp. III, 1962). For 1963, see the paragraph on "International Organizations and Conferences" in 76 Stat. 1080 (1962).

14275 Stat. 433 (1961), as amended, 22 U.S.C. $\$ 2222$ (Supp. III, 1962).

143 See, e.g., Foreign Aid and Related Agencies Appropriation Act, 1963, 76 Stat. 1163 (1962) ("Economic Assistance").

144 The assessed contributions are considered by the House Subcommittee on State, Justice, Commerce, and the Judiciary, chaired recently by John D. Rooney (D., N.Y.). Voluntary contributions are considered by the House Subcommittee on Foreign Operations, chaired recently by Otto Passman (D., La.). The authorizing legislation, however, is likely to be considered by the House Foreign Affairs Committee.

${ }^{145}$ See Hearings on the Departments of State, Justice, and Commerce, the Judiciary, and Related Agencies Appropriations Act, 1963, Before a Subcommittee of the House Committee on Appropriations, 87th Cong., 2d Sess. 1088-89 (1962).

146 The Office of International Administration in the Bureau of International Organization Affairs.

14775 Stat. 433 (1961), 22 U.S.C. $\$ 2221$ (b) (Supp. III, 1962). Other limitations in authorizing legislation include: $25 \%$ for contributions to the International Labor Organization, 72 Stat. 273 (1958), 22 U.S.C. \$272a (1958), and some stated dollar limitations such as $\$ 100,000$ for the South Pacific Commission, 74 Stat. 141 (1960), 22 U.S.C. $\$ 280$ b (Supp. III, 1962).

148 See Hearings on S. 2768 Before the House Committee on Foreign Affairs, 87th Cong., 2d Sess. 374-75 (1962), indicating that U.S. contributions to ONUC and UNEF have been as follows:

\section{PerIod}

July to Dec. 1960

Jan. to Oct. 1961

Nov. 1961 to June 1962

Grand Total (ONUC)
ONUC

\begin{tabular}{rcrrr} 
& \multicolumn{1}{c}{ ONUC } & & \multicolumn{1}{c}{ PER } \\
ASSESSED & VolUNTARY & \multicolumn{1}{c}{ TOTAL } & CENT & U.N. BUDGET \\
$\$ 15,745,211$ & $\$ 14,217,622 *$ & $\$ 29,962,833$ & 49.94 & $\$ 60,000,000$ \\
$32,204,061$ & $15,305,596$ & $47,509,657$ & 47.51 & $100,000,000$ \\
$25,616,000$ & $11,400,800$ & $37,016,800$ & 46.27 & $80,000,000$ \\
& & $\$ 114,489,290$ & 47.70 & $\$ 240,000,000$
\end{tabular}


untary contributions is used as an argument to counteract criticism of the ceiling principle, which only affects the U.S. ${ }^{149}$

Complaint against the amount of U.S. total contributions seems inappropriate. For 1962, for instance, the United States contributed (both voluntary and assessed) $\$ 235,405,000$ of the total of $\$ 502,307,000$ expenditures of the U.N., its programs, and the specialized agencies of the U.N. (WHO, UNESCO, etc.), a percentage (over 46 per cent) somewhat greater than various statements mentioned above about the U.S. ability to pay based on national mcome statistics. ${ }^{150}$ These figures do not indicate the whole nature of the problem, for it must be recognized that it is more pleasant to make voluntary contributions than it is to pay tax. Even more significant, voluntary contributions obviously give the contributor considerably more power and influence on an operation, since they are more easily withdrawn or conditioned upon specific allocation or emphasis. One argument for the ceiling principle - that the organization should not be too dependent on the contributions of any one nation, because this gives that nation too much power over the Organization-is, in fact, an argument for higher assessments and lower voluntary contributions, since as between the two, assessed contributions probably give the contributor less power. One might reasonably be skeptical of U.S. arguments for a lower ceiling based on preventing political dominance of one nation, when the effect of a lower ceiling is in fact to render the Organization more dependent on voluntary contributions by the U.S. This, of course, is precisely what appears to have lappened in the UNEF and ONUC operations. ${ }^{151}$

$\begin{array}{lrcrrr}\text { Nov. } 1956 \text { to Dec. 1958 } & \$ 13,023,563 & \$ 14,112,431 * & \$ 27,135,994 & 49.34 & \$ 55,000,000 \\ 1959 & 4,943,146 & 3,500,000 & 8,443,146 & 44.44 & 19,000,000 \\ 1960 & 6,497,064 & 3,200,000 & 9,697,064 & 48.48 & 20,000,000 \\ 1961 & 6,115,519 & 1,800,000 & 7,915,519 & 41.66 & 19,000,000 \\ 1962 & 3,121,950 & 1,320,000 & 4,441,950 & 45.56 & 9,750,000 \\ \text { Grand Total (UNEF) } & & & \$ 57,633,673 & 46.95 & \$ 122,750,000\end{array}$

*Includes waiver of initial airlift:

ONUC (fiscal year $1961 \mathrm{MSA}$ ) $\$ 10,317,622$

UNEF (fiscal year 1957) \$1,191,581

149 See U.N. Gen. Ass. OFF. REc. 17th Sess., 5th Comm. 15 (A/C.5/SR.975) (provisional) (1962) (statement of Ambassador Klutznick).

150 Letter fron the Acting Secretary of State to the Speaker of the House of Representatives, United States Contributions to International Organizations, H.R. Doc. No. 460, 87th Cong., 2d Sess. 136, 139 (1962). See Ambassador Klutznick's statement, supra note 149.

151 When one adds the credit which the United States has extended to ONUC (about $\$ 31$ million as of March 31, 1962) to its contributions, voluntary and assessed (over $\$ 114$ million), conjpared to a total budget of $\$ 240$ million (see Hearings on S. 2768, supra note 148 , at 361,374 ), it is quite clear that but for United States policy ONUC could never have been carried through. United States voluntary support could have been withdrawn at any time and ONUC would probably have had to shut down operations. Obviously it was considered very much in the policy interests of the Umited States to continue. See Address by the Honorable Harlan Cleveland, Assistant Secretary of State for International Organization Affairs, Jan. 17, 1963, U.S. Dep't of State, Press Release No. 34, Jan. 17, 1963. 


\section{V}

\section{DEVELOPMENT OF THE FINANCIAI CRISIS}

With the addition of the current rates of authorization for UNEF and ONUC to the regular U.N. budget, U.N. assessments are almost tripled. ${ }^{152}$ It would be indeed surprising if some stress did not develop in the U.N. financial system under these circumstances.

The essential trouble does, in fact, lie with UNEF and ONUC, and it lies in the refusal of many countries to pay their assessments for these funds. The payment record for the U.N. General Fund has been a sterling 99 per cent. Payment of UNEF assessments, however, has been only about 75 per cent, and of ONUC, 64 per cent. ${ }^{153}$

\section{A. UNEF}

It all began after the fast moving crisis in Suez had developed when the General Assembly, in November 1956, following a week of harried negotiations, approved a plan for the establishment of a buffer zone manned by U.N. troops between Egypt and Israel. ${ }^{154}$ The principle was enunciated that each nation furnishing troops would pay for the equipment and salaries, while extraordinary costs would be paid by the U.N..$^{155}$ On November 21 the Secretary-General recommended a special account for UNEF outside the regular budget, apparently because he wanted funds immediately, and thought the regular budget process would cause delay. His report recommended, however, that the special account be financed through assessments according to the regular scale. ${ }^{156}$ The General Assembly on November 26 authorized the special account in an mitial amount of $\$ 10$ million, and authorized the Secretary-General to establish rules for the account. ${ }^{157}$

The General Assembly on December 21, 1956, noted the Secretary-

152 UNEF, $\$ 1,580,000$ per month or $\$ 18,960,000$ per year. UN. Gen. Ass. Res. No. 1864 (XVII) (Dec. 20, 1962). ONUC, $\$ 10$ million per month or $\$ 120$ million per year. U.N. Gen. Ass. Res. No. 1865 (XVII) (Dec. 20, 1962). The assessed portion of the regular UN. budget, $\$ 89,406,446$ for 1963. U.N. Gen. Ass. Res. No. 1861, pt. C (XVII) (Dec. 20, 1962). Total, $\$ 228,366,446$.

153 See Statement on the Collection of Contributions as at 31 December 1962, U.N. Doc. No. ST/ADM/SER.B/168, at 27 (1963).

154 See U.N. Gen. Ass. Res. Nos. 997-1003 (ES-I) (1956); FrYe, A UNITEd Nations PEACE FORCE 195 (1957).

155 Secretary-General, Report, U.N. Gen. Ass. OFF. Rec. 1st Emer. Sp. Sess., Annexes, Agenda Item No. 5, para. 15 (A/3302) (1956), as approved, U.N. Gen. Ass. Res. No. 1001, para. 5 (ES-I) (1956).

150 U.N. Gen. Ass. Off. Rec. 1st Emer. Sp. Sess., Annexes, Agenda Item No. 5, at 21 (A/3302) (1956); see Secretary-General, Summary Study on UNEF, U.N. GeN. Ass. OFF. REc. 13th Sess., Annexes, Agenda Item No. 65, at 21 (A/3943) (1958); U.N. GeN. Ass. OFF. Rec. 11th Sess., Annexes, Agenda Item No. 66, at 14 (A/3383) (1956).

157 U.N. Gen. Ass. Res. No. 1122 (XI) (1956). 
General's recommendations to finance UNEF by the regular scale, but noted also "that several divergent views, not yet reconciled, have been held by various Member States on contributions or on the method suggested by the Secretary-General for obtaining such contributions." Nevertheless it decided to apportion the $\$ 10$ million already authorized for UNEF according to the regular scale, "without prejudice to the subsequent apportionment of any expenses in excess of $\$ 10$ million which may be incurred in connexion with the Force."1158

The inevitable soon occurred-UNEF costs threatened to exceed $\$ 10$ million. On February 27, 1957, the General Assembly authorized the Secretary-General to incur expenses for UNEF up to $\$ 16.5$ million to the end of 1957 , and in order to finance the amount over $\$ 10$ million "invited" member States to make voluntary contributions. ${ }^{159}$ Most of the $\$ 6.5$ million was in fact contributed by the U.S. and Great Britain. ${ }^{100}$

The assessment resolutions from 1957 onward form a chorus of unsuccessful attempts to arrive at a method of financing for UNEF acceptable to the members of the U.N. Amid widely divergent views of the principles to be used in obtaining the money, the General Assembly has groped for a solution, using a combination of assessments and voluntary contributions. ${ }^{11}$ The latest resolution assessing members for UNEF (the same is true for ONUC) starts with the regular scale. It then provides for a series of decreases in the percentages of smaller members, 80 per cent for most of those in the 0.04 to 1.25 per cent bracket) while calling for voluntary contributions to make up the gap. It is thus a "special scale" of assessments for the particular purpose involved. ${ }^{102}$

From the beginning the UNEF account was in trouble as to collections. Waivers of some initial expenses (e.g., airlift) provided some help, but at the end of 1957 arrears began to grow. Some members denied an obliga-

\footnotetext{
158 U.N. Gen. Ass. Res. No. 1089 (XI) (1956).

159 U.N. Gen. Ass. Res. No. 1090 (XI) (1956).

160 See Stoessinger, supra note 3 , at 18.
}

101 After approving additional funds for 1957 and 1958, the General Assembly stated that "such other resources as may become available" for the purpose would reduce the expenses before apportionment. U.N. Gen. Ass. Res. No. 1151 (XII) (1957). Likewisc, the appropriation for 1959 ( $\$ 19$ million) was reduced by voluntary contrihutions before being assessed. U.N. Gen. Ass. Res. No. 1337 (XIII) (1958). The 1960 appropriations ( $\$ 20$ million) were assessed, and voluntary contributions were applied to reduce by $50 \%$ the assessments of as many members as possible, starting with the lowest assessed members and working up. U.N. Gen. Ass. Res. No. 1441 (XIV) (1959). The 1961 appropriations ( $\$ 19$ million) were also assessed by the regular scale, with voluntary contributions being used to the extent available to reduce the assessments by $50 \%$ of those states in the several specified classes. U.N. Gen. Ass. Res. No. 1575 (XV) (1960). For 1962 the first half year's appropriation was assessed according to the regular scale, except that specified reductions were made in the scale (this time not contingent on voluntary contributions), and an "appeal" was made to member States to contribute voluntarily to make up the gap caused by the reductions. U.N. Gen. Ass. Res. No. 1733 (XVI) (1961).

162 U.N. Gen. Ass. Res. No. 1733 (XVI) (1961). 
tion to pay for UNEF. Others, while recognizing their obligation, claimed financial inability to pay the amounts. ${ }^{163}$ UNEF arrears have continued to grow, reaching over $\$ 27$ million by the end of $1962 .{ }^{164}$

\section{B. The Congo}

The Congo financial story is similar to the UNEF experience, but six times as costly. Pursuant to Security Council resolutions in July and August of 1960 (UNEF was authorized by the General Assembly), an international force of troops was rushed to the Congo. ${ }^{165}$ The basic principles of financing were to be the same as for UNEF-the U.N. was responsible only for the extraordinary costs of maintaining the troops in the Congo, the troop-supplying nations bearing the ordinary costs such as equipment and salary ${ }^{100}$ Again, the General Assembly turned to a special or ad hoc account. The first resolution, for 1960, expressly states that Congo expenses "constitute 'expenses of the Organization' within the meaning of Article 17, paragraph 2, of the Charter," but notes that these extraordinary expenses "will place a severe strain on the limited financial resources of a number of Member States." The resolution adopted the 1960 UNEF inethod of assessments, applying voluntary contributions to reduce the assessments of members with low percentage shares. ${ }^{167}$

The later Congo financial resolutions of the General Assembly, for January through October $1961,{ }^{168}$ and then for November 1961 through June $1962,{ }^{160}$ however, contain the following significant clauses:

Bearing in mind that the extraordinary expenses for the United Nations operations in the Congo are essentially different in nature from the expenses of the Organization under the regular budget and that therefore a procedure different from that applied in the case of the regular budget is required for meeting these extraordinary expenses,

Bearing in mind that the permanent members of the Security Council have a special responsibility for the inaintenance of international peace and security and therefore for contributing to the financing of peace and security operations....

183 See Secretary-General, Report on Consultations With Governments of Member States, U.N. Gen. Ass. OFF. Rec. 14th Sess., Annexes, Agenda Item No. 28, at 13 (A/4176 \& Add. 1-2) (1959).

164 See Statement, supra note 153, at 27.

165 The Security Council resolutions on the Congo are as follows: U.N. Security Council Res. S/4387 (873d meeting) (1960); S/4405 (879th meeting) (1960); S/4426 (886th meeting) (1960) ; S/4741 (942d meeting) (1961) ; S/5002 (982d meeting) (1961).

160 The Secretary-General stated in the Security Council that the principles of UNEF, as expressed in his report A/3943, supra note 156 , would be followed. U.N. SEcuRITY Councrr, 15th year, 873d meeting, para. 28 (S/PV.873) (1960). Report A/3943 set out the principles of reimburseinent for costs of troop contingents in paragraph 117.

167 U.N. Gen. Ass. Res. No. 1583 (XV) (1960).

168 U.N. Gen. Ass. Res. No. 1619 (XV) (1961).

169 U.N. Gen. Ass. Res. No. 1732 (XVI) (1961). 
Both of these resolutions assess members in the same manner as described above for the 1962 UNEF expenses, i.e., basing assessments on the regular scale with reductions for certain members, "pending the establishment of a different scale of assessment to defray the extraordinary expenses of the Organization resulting from these operations."170 The resolutions call for voluntary contributions to make up the gaps caused by the reductions.

Once again the Soviet bloc refused to pay any assessments to this special account, and this time France also refused to pay. Other members either refused or would not pay, and arrears began mounting in this new account. ${ }^{171}$ Once again the General Assembly groped for a solution, and similar to its UNEF practice asked members to submit views; twenty-two replies were received. ${ }^{172}$

At the same time the General Assembly appointed a working group of fifteen members to consider methods of covering the costs of peacekeeping operations. ${ }^{173}$ After much discussion, the Working Group took a number of votes on a variety of alternatives and finally concluded that, "It was not possible for the Working Group to find a sufficiently large area of agreement out of which it could present a set of recommendations for consideration by the General Assembly." 174

If the UNEF problem appeared acute at the end of 1959, the U.N. financial picture was many times darker by the end of 1961. The Congo account was over $\$ 54$ million in arrears, which, when added to UNEF's $\$ 26$ million, presented a grim $\$ 80$ million story in red ink. ${ }^{175} \mathrm{It}$ was at this time that the General Assembly, in a double barreled attempt to solve the problem, adopted the bond issue proposal and passed the resolution requesting the World Court opinion. ${ }^{176}$

\section{The U.N. Financial Position and Its Causes}

The financial crisis is easily traceable to precisely one cause-the failure of members to pay assessments for UNEF and ONUC. But behind that simple statement one can inquire further. Why have members refused to pay? Because they can't afford to? Or don't want to? Or don't believe they should? Or are trying to destroy the effectiveness of the Organization?

170 Ibid.

171 See U.N. Gen. Ass. OfF. Rec. 15th Sess., Annexes, Agenda Item No. 49/50 (A/C.5/860) (1961), for statements of some members on U.N. financing. For the U.S.S.R. view see id. at 28. 172 U.N. Gen. Ass. Res. No. 1620 (XV) (1961). The replies are contained in U.N. Doc. Nos. A/AC.104/I \& Add. 1-8 (1961).

173 U.N. Gen. Ass. Res. No. 1620 (XV) (1961).

174 Report of the Working Group of Fifteen, U.N. GEN. Ass. OFF. REc. 16th Sess., Annexes, Agenda Item 62, at 6 (A/4971) (1961).

175 Statement of the Collection of Contributions as at 31 December 1961, U.N. Doc. No. ST/ADM/SER.B/154, at 25 (1962). See also Hearings on S. 2768, supra note 148, at 366-73. 176 U.N. Gen. Ass. Res. Nos. 1731, 1739 (XVI) (1961). 
The composition of the arrears gives immediate clues to the answers to these questions. Of the total arrears of $\$ 103,856,251.42$ on December 31, 1962 , the following were the largest: ${ }^{177}$ Soviet bloc, $\$ 69,715,039$ (57.3 per cent); France, $\$ 15,246,015$ (12.5 per cent); and China, $\$ 15,865,360$ (13.0 per cent). The U.S.S.R. and its satellite nations argue that the assessments for UNEF and ONUC are illegal. ${ }^{178}$ France argues that ONUC assessments are illegal. ${ }^{179}$ China has trouble paying, apparently because she is assessed on the basis of representing all of mainland China, but has only the resources of Taiwan to draw upon. ${ }^{180}$ The other countries have varying reasons for not paying, but the aggregate arrears of all these others is less than 18 per cent of the total. ${ }^{181}$ If it were not for the arrears of France and the Soviet bloc, there would be no financial crisis, and it is clear that the causes behind these arrears are political, not economic or financial.

The smaller arrears of the other countries, however, do have an impact greater than their monetary aggregate. "World pressure" of the small members of the U.N. has worked effectively before, ${ }^{182}$ and could work again to help obtain payment of arrears, but members who are themselves in arrears would have difficulty in bringing such pressure. In addition, it is difficult to obtain stricter financial measures in the General Assembly, or from the Secretariat, when a large number of members are delinquent.

It would be presenting an incomplete picture of the crises if at least two other possible causes were not inentioned. First is the lack of confidence in the fairness of the present assessment process, at least as applied to the greater sums involved for peacekeeping. This lack of confidence is evidenced by the large number of States in arrears, by the expressed views of many of these States, and by the express declarations included in the 1961 Congo appropriation resolutions..$^{183}$ The arguments against the system are several. The smaller nations, although able to afford their percentage shares of the regular budget (totalling about $\$ 70$ to $\$ 80$ million), can claim they cannot afford the same percentage when the absolute amount is

177 Statement on the Collection of Contributions as at 31 December 1962, U.N. Doc. No. ST/ADM/SER.B/168 (1963).

178 Report of the Working Group of Fifteen, supra note 174, at 7-8 (observations of Bulgaria and the U.S.S.R.) ; CERTAIN ExPEnSES of tHe UNITED Nations-Pleadings, Oral ARguMEENTS, AND DOCUMENTS 270 (I.C.J. 1962) (memorandum of the U.S.S.R.) ; see Memorandum of the Government of the USS.R., U.N. GEN. Ass. OFF. REc. 17th Sess., Annexes, Agenda Item No. 64 (A/C.5/957) (Dec. 6, 1962).

170 Lettre du Gouvernement de la République Française au Greffier de la Cour, 15 Février 1962, Certain EXPEnses of the UNITEd Nations-Pleadings, supra note 178, at 130.

180 An assessment of $4.57 \%$ could only be explained this way. See appendix.

181 See notes 174 \& 177 supra.

${ }^{182}$ For instance, in obtaining U.S.S.R. concurrence in the election of $U$ Thant as Acting Secretary-General of the U.N. in 1961, despite an initial Russian attempt to obtain a "Troika" system for the U.N.

183 See text accompanying notes $168,169,174$ \& 177 supro. 
almost tripled by the addition of $\$ 140$ million for peacekeeping expenses. For the countries now assessed at the floor of 0.04 per cent, numbering thirty-six at present, this problem is arguably more acute. If a floor or minimum is established with an absolute sum mind (say about $\$ 30,000$, which approximates 0.04 per cent of the regular budget), then when unusual assessments triple the sum the minimum has lost the significance originally attached to it. Furthermore, it can be argued, the ceiling principle allows the U.S. to escape its full share of the cost, thereby imposing an added burden on the small countries. Finally there is the argument that certain more powerful nations have a greater relative responsibility in the area of peacekeeping, as recognized by the charter in establishing the Security Council..$^{184}$

A second factor of importance is the continued reluctance to give support to the U.N., especially by big powers, due either to a distrust of it as an institution, or to a feeling that it is not very important. ${ }^{185}$ Part of this distrust stems from suspicions of a new bureaucracy remote from the grassroots of politics. In the U.S., for instance, individuals who write Congressmen, and Congressinen themselves, hear stories about the alleged opulent living of U.N. delegations; they experience inefficiencies, impoliteness, or poor public relations on the part of U.N. Secretariat officials who have an enviable position of tenure and privilege; they read about overlap or confusion among the proliferation of organizations that exist on the international scene. As the U.N. budget steadily advances, they see their nation and themselves committed indefinitely to large contributions, with all the evils of Parkinson's law operating to take their hard earned dollars, without anything concrete being received in exchange. That these suspicions, even if true, should be weighed against the alternatives, is hard to understand. Few seem willing to risk a bit of wastefulness in the U.N. to save the costs (both in dollars and lives) of a Korean (or worse) type engagement.

Suspicion of bureaucracy is not the only cause of reluctance for support of the U.N. by big powers. As power within the U.N. shifts to the General Assembly due to stalemates in the Security Council, ${ }^{188}$ and the General

184 See text accompanying notes 168-69 supra.

185 See H.R. REP. No. 2176, 87th Cong., 2d Sess. 9 (1962):

Under the conditions existing in the world today, the United States must exercise extreme caution both as to its role in the United Nations and as to the extent to which the United States becomes dependent on the United Nations in the conduct of our foreign policy.

-..

The United States cannot disregard the danger that in the future we, together with other nations similar in outlook and interests, may be ontvoted by "have-not" governments lacking in experience and responsibility.

186 In abusing the veto power, the U.S.S.R. has contributed in a major way to the decline of Security Council power, and thus, ironically, to big power influence in the U.N. The prime example illustrating this result is the 1950 "Uniting for Peace" resolution, U.N. Gen. Ass. Res. 
Assembly grows larger and larger with the admission of new members, ${ }^{187}$ the big power voice in U.N. affairs is diluted even though the five permanent Security Council members are assessed almost 70 per cent of the total regular budget and effectively contribute a higher percentage of U.N. expenses. A powerful nation may well wonder whether its money won't produce greater returns outside the U.N., for example, in regional or bloc organizations, where its effective control is much greater. Withholding funds from the U.N. is, of course, a means of making one's weight felt in more force than by mere voting. Perhaps the willingness of members to extend credit to the U.N., and to provide troops on a voluntary basis, even while, in some cases, not paying their assessments, ${ }^{188}$ is a manifestation of the desire to support specific policies of the U.N. while retaining a greater choice of which policies to support.

Whatever the causes, the problem is Gordion. The World Court opinion is a ray of light, but a very weak ray. ${ }^{189}$ Even with ONUC and UNEF expenditures as "expenses of the organization," the application of article 19 of the charter is a very weak sanction for nonpayment. ${ }^{190}$ First, the loss of vote only applies in the General Assembly, and not in other bodies such as the Security Council. Second, the loss of vote is only for an arrearage that "equals or exceeds the amount of contributions due ... for the preceding two full years." As yet, no nation has been subject to this sanction. ${ }^{191}$ In the case of the U.S.S.R., it has been calculated that this night occur sometinie in $1964 .^{102}$ In the case of France, with arrears of $\$ 14$ million,

No. 377A (V) (1950), which provides for General Assembly cognizance if a veto prevents Security Council action. This resolution was adhered to following a Security Council veto during the Suez crisis in 1956 and at one point in the Congo crisis in 1960.

$187 \mathrm{Six}$ new nnembers were admitted in 1962 . The membership now totals 110 . Secretariat officials are planning for 126 members withim a few years. See note 58 supra.

188 Hearings on S. 2768 , supra note 148, at 396 , gives the composition of the Congo forces. Of the countries represented, Austria, Brazil, Ethiopia, and Italy were at that time in arrears on the Congo account for 1961 or before. Id. at 366 . It may be surmised that some of these arrears were due to the fact that the U.N. owed these countries for reimbursable costs of furnishing troop contingents, and these countries were waiting until a set-off could be arranged.

189 See discussion in part VI, following note 205 infra.

190 See discussion in part $I$, following note 3 supra.

191 As far as is known, no State having arrears equaling the article 19 amount has voted in the General Assembly, although there have reputedly been some close cases where last minute payment saved the showdown. In one case, when a check missed the deadline, the delegation (Bolivia) absented itself during voting. See Stoessinger, supra note 3, at 60. "Most of the specialized agencies have equivalents of Article 19 in their Charters, and precedents for their invoeation exist." Ibid.

102 U.S.S.R. arrears total $\$ 46,271,050$. Its 1962 assessments were: Regular, $\$ 11,096,380$; UNEF, $\$ 1,459,575$; ONUC, $\$ 11,976,000 \times 6 / 8=\$ 8,997,000$; Total, $\$ 21,552,955$. If no assessments for UNEF and ONUC are made in 1963, the total for 1963 (regular budget) will be $\$ 11,951,498$. The assessments for the two years together will thus be exceeded by arrears. See Hearings on S. 2768, supra note 148, at 366; Statement on the Collection of Contributions as at 31 December 1962, U.N. Doc. No. ST/ADM/SER.B/168 (1963). 
the sanction point may also be reached in $1964 .^{103}$

One encouraging aspect of the U.N. financial crisis is the financial staying power displayed by the U.N. Three years ago it would have seemed doubtful, at best, that the U.N. could proceed in the face of a "deficit" of over $\$ 100$ million without drastic curtailment of any of its functions, but that in fact is what it has done. How it has managed to do so can be gleaned from the extensive financial tables presented to the U.S. Congress in connection with the "Bond Bill." These figures show that of a "deficit" of $\$ 119$ million on March 31, 1962, about $\$ 10$ million net was owed to internal U.N. accounts, such as the Working Capital Fund. Over $\$ 86$ million of the accounts payable was due to member States ( $\$ 32$ million of this to the U.S.). The remainder, only about $\$ 23$ million, was owed chiefly to private creditors. ${ }^{104}$ It can be surmised, as an oversimplification, that the U.N. financial position is about as good as its creditor-members will allow it to be. With the subsequent sales of U.N. bonds, plus an improvement in the Katanga problem ${ }^{105}$ which should mean a drop in military expenses, the U.N. financial picture could be looking brighter, even if arrears are not paid. The underlying political problems, however, remain unresolved.

\section{The Bond Issue}

At its sixteenth session, the General Assembly adopted two measures designed to seek a way out of the financial difficulty. The first was a request for a World Court opinion on finances. ${ }^{190}$ The second was an authorization for the Secretary-General to issue up to $\$ 200$ million of bonds to be sold to members of the U.N. and its specialized agencies. Each year's regular budget of the U.N. is to include an amount sufficient to pay the interest and principal installments on these bonds. ${ }^{107}$

Special legislation to authorize U.S. purchase of the bonds was introduced in Congress in $1962 .{ }^{108}$ Hearings were held, in both the House and

193 French arrears total $\$ 14,186,015$. French assessments for 1962 were: Regular, $\$ 4,402,972$; UNEF, $\$ 579,150$; ONUC, $\$ 4,752,000 \times 6 / 8=\$ 3,564,000$; Total, $\$ 8,546,122$. For 1963 , French assessed contributions (assuming no UNEF or ONUC assessments) will be about $\$ 4,667,510$. Thus arrears would exceed two prior years contributions by about $\$ 1$ million. If assessments increase in 1964, however, France may not come under the article 19 sanction in 1964. In fact, if no further ONUC assessments are made, and assuming there are continued increases in the annual regular budget, it is conceivable that ONUC arrears would never force France within the sanction of article 19.

194 Hearings on S. 2768 , supra note 148 , at 360-61.

105 See Hamilton, Congo Problem Still Besets U.S., N.Y.Times, Mar. 4, 1963, p. 10, col. 6. 196 U.N. Gen. Ass. Res. No. 1731 (XVI) (1961).

107 U.N. Gen. Ass. Res. No. 1739, para. 3 (XVI) (1961); see Budget Appropriations for 1963, U.N. Gen. Ass. Res. No. 1861, § 12 (XVII) (1962).

198 S. 2768, 87th Cong., 2d Sess. (1962). 
the Senate, ${ }^{100}$ with some intensive and hostile questioning. ${ }^{200}$ U.S. officials testifying before Congress stated that the proceeds of the bond sales would be for future expenses of the special operations. ${ }^{201}$ Finally, at the end of the summer, legislation was adopted that would authorize U.S. purchase of up to $\$ 100$ million of U.N. bonds, but in no greater amount than the aggregate purchased by all other nations. ${ }^{202}$

Since the General Assembly authorized expenditures for UNEF and ONUC for all of 1962, but made provision for financial sources (assessments and contributions) only for the first half of the year, ${ }^{203}$ the implication exists that bond money would pay for the balance of these operations. The bond resolution authorizes use of the proceeds "for purposes normally related to the Working Capital Fund," phraseology which is ambiguous enough to allow for this interpretation. ${ }^{204}$

On December 21, 1962, Ambassador Stevenson announced that total U.S. purchases of U.N. bonds amounted to $\$ 59,672,840 .{ }^{205}$ Thus U.N. bonds sold to all countries, including the U.S., must have been at least double that figure, or $\$ 119,345,680$.

\section{VI}

THE WORLD COURT OPINION AND ITS AFTERMATH

Acting upon the report of the Working Group of fifteen, the Fifth Committee of the General Assembly, in 1961, voted to recommend a resolution requesting an opinion from the International Court of Justice under article 96 of the charter as to whether UNEF and ONUC expenses were "expenses of the Organization" within article 17. ${ }^{208}$ The General Assembly adopted this resolution, ${ }^{207}$ despite arguments: (1) that such procedure

190 Hearings on S. 2768, supra note 148; Hearings on S. 2768 Before the Senate Committee on Foreign Relations, 87th Cong., 2d Sess. (1962).

200 E.g., Hearings on S. 2768, supra note 148, at 63.

201 Hearings on S. 2768, supra note 148, at 29.

20276 Stat. 695 (1962).

203 U.N. Gen. Ass. Res. Nos. 1732, 1733 (XVI) (1961).

204 U.N. Gen. Ass. Res. No. 1739 (XVI) (1961). See also Hearings on S. 2768, supra note 148 , at $30-33$.

205 Statement by Adlai E. Stevenson, at a press conference at U.N. headquarters on Dec. 21, 1962, 48 Dep't State Buld. 147 (1963); U.S. Delegation Press Release No. 4137, Dec. 21, 1962. 200 U.N. GEN. Ass. OfF. REc. 16th Sess., Annexes, Agenda Item No. 62, at 16 (A/5062) (1961).

207 U.N. Gen. Ass. Res. No. 1731 (XVI) (1961). Article 96 of the United Nations Charter states:

1. The General Assembly or the Security Council may request the International Court of Justice to give an advisory opinion on any legal question.

2. Other organs of the United Nations and specialized agencies, which may at any tine be so authorized by the General Assenbly, may also request advisory opinions of the court on legal questions arising within the scope of their activities.

The International Court of Justice is constituted by article 92 of the U.N. Charter, which states: "The International Court of Justice shall be the principal judicial organ of the United 
would only delay a definitive answer; (2) that the Security Council should make the interpretation or at least the request; (3) that since the national representation on the Court was very similar to that of the Working Group of fifteen, no better result could be expected from it than from the Working Group; ${ }^{208}$ and (4) that, at least, the draft resolution should have been discussed by the Sixth (Legal) Committee before General Assembly action. ${ }^{200}$

Part of the discussion centered on the problem of phrasing the question for the Court. Some delegates felt that the question should have in-

Nations. It shall function in accordance with the annexed Statute, which is based upon the Statute of the Permanent Court of International Justice and forms an integral part of the present Charter."

Under the statute, the Court's jurisdiction is principally of two kinds: Contentious, i.e., cases between States, Stat. InT'x CT. Just. arts. 34-38; and Advisory, Stat. INT'2 CT. Just. arts. 65-68. Since its establishinent in 1945, the Court has rendered final judgments in ninctecn contentious cases, and has given advisory opinions in answer to twelve requests, including the 1961 request for an opinion on U.N. finances. Of the twelve requests for advisory opinions, ten were made by resolution of the General Assembly, one was a request by the Executive Board of United Nations Educational Scientific and Cultural Organization (UNESCO) in 1955, and one was a request by the Assembly of the Inter-Governmental Maritime Consultative Organization in 1959. See [1960-1961] I.C.J.Y.B. 43-81; [1960], [1961], [1962] I.C.J. Rep.

At present eighteen bodies or agencies have been authorized by the General Assembly to request opinions from the I.C.J., including four principal and subsidiary organs of the U.N. and fourteen of the fifteen specialized agencies (omitting only the Universal Postal Union). See [1960-1961] I.C.J.Y.B. 192-94.

208 See A/506.2, supra note 206.

209 In U.N. Gen. Ass. Res. No. 684 (VII) (1952), the General Assembly recommended:

That, whenever any Conmittee contemplates making a recommendation to the General Assembly to request an advisory opinion fron the International Court of Justice, the matter may, at some appropriate stage of its consideration by that Committee, be referred to the Sixth Coninittee for advice on the legal aspects and on the drafting of the request, or the Cominittee concerned may propose that the matter should be considered by a joint Committee of itself and the Sixth Committee ....

At the time this resolution was adopted, six requests for advisory opinions had been made by the General Assembly, originating as follows: one in the First Committce, U.N. Gcn. Ass. Res. No. 113B (II) (1947); two in the Ad Hoc Political Cominittee, UN. Gen. Ass. Res. Nos. 294, 296J (IV) (1949); one in the Fourth Coununittee, U.N. Gen. Ass. Res. No. 338 (IV) (1949); and two in the Sixth Cominittee, U.N. Gen. Ass. Res. Nos. 258 (III) (1948), 478 (V) (1950). It was stated in the discussion on the voted recommendation, supra, that "it is noteworthy that the Court has been obliged to edit several of the requests addressed to it, which have originated from political or technical committees, due to the faulty or defective drafting of these requests." U.N. Gen. Ass. OFF. Rec. 6th Sess., Annexes, Agenda Item No. 63, at 2 (A/1929) (1951).

The four requests for advisory opinions made subsequent to the adoption of the recommendation in resolution 684 by the General Assembly have originated as follows: one in the Fifth Committee, U.N. Gen. Ass. Res. No. 795A (VII) (1953); two in the Fourth Committee, U.N. Gen. Ass. Res. Nos. 904 (IX) (1954), 942 (X) (1955); and the request for the opinion on U.N. expenses, which also originated in the Fifth Committce, U.N. Gen. Ass. Res. No. 1731 (XVI) (1961). In the requests for ICJ opinions made prior to resolution 684 , the procedure normally followed for other resolutions was used. The same can be said for the subsequent resolutions, for no request for an advisory opmion has been referred to the Sixth Committec prior to adoption by the General Assembly. See 5 Repertory of UnTted Nations Practice 40 (U.N. Pub. Sales No. 1955.V.2); 2 id. Supp. No. 1, at 318 (U.N. Pub. Sales No. 1957.V.4). 
cluded the general question of financing U.N. peacekeeping actions. ${ }^{210}$ As finally phrased, however, the question could scarcely have been more narrowly defined. It read:

Do the expenditures authorized in General Assembly resolutions 1583 (XV) and 1590 (XV) of 20 December 1960, 1595 (XV) of 3 April 1961, 1619 (XV) of 21 April 1961 and 1633 (XVI) of 30 October 1961 relating to the United Nations operations in the Congo undertaken in pursuance of the Security Council resolutions of 14 July, 22 July and 9 August 1960 and 21 February and 24 November 1961, and General Assembly resolutions 1474 (ES-IV) of 20 September 1960 and 1599 (XV), 1600 (XV) and 1601 (XV) of 15 April 1961, and the expenditures authorized in General Assembly resolutions 1122 (XI) of 26 November 1956, 1089 (XI) of 21 December 1956, 1090 (XI) of 27 February 1957, 1151 (XII) of 22 November 1957, 1204 (XII) of 13 December 1957, 1337 (XIII) of 13 December 1958, 1441 (XIV) of 5 December 1959 and 1575 (XV) of 20 December 1960 relating to the operations of the United Nations Emergency Force undertaken in pursuance of General Assembly resolutions 997 (ES-I) of 2 November 1956, 998 (ES-I) and 999 (ES-I) of 4 November 1956, 1000 (ES-I) of 5 November 1956, 1001 (ES-I) of 7 November 1956, 1121 (XI) of 24 November 1956 and 1263 (XIII) of 14 November 1958 , constitute "expenses of the Organization" within the meaning of Article 17, paragraph 2, of the Charter of the United Nations? ${ }^{211}$

This phrasing obviously was an attempt to prevent the Court from going into the broader questions of financing peacekeeping and of the charter authority for ONUC and UNEF, an attempt which, as we shall see, partly failed.

In accordance with its procedure in advisory opinions, ${ }^{212}$ the International Court of Justice invited all members of the U.N. to submit written statements, ${ }^{213}$ and after hearing oral statements, ${ }^{214}$ the Court rendered

$210 \mathrm{~A} / 5062$, sucpra note 206 , at 15 . Article 65 (2) of the Statute of the International Court of Justice states: "Questions upon which the advisory opinion of the Court is asked shall be laid before the Court by means of a written request containing an exact statement of the question upon which an opinion is required, and accompanied by all documents likely to throw hight upon the question."

211 U.N. Gen. Ass. Res. No. 1731 (XVI) (1961).

212 Article 66 of the Statute of the International Court of Justice, as supplemented by articles 82-85 of the Rules of the Court, set forth the procedure to be followed. This procedure was apphed in the U.N. expenses case by an order of the Court. Financial Obligations of Members of the United Nations, Order of 27 December 1961, [1961] I.C.J. Rep. 64. The order fixed Feb. 20, 1962, as the time limit for written statements. Later, the Court set oral proceedings in the case which were held May 14-19, 21, 1962. See Certain Expenses of the United Nations, [1962] I.C.J. Rep. 151, 154.

213 Written statements were submitted by Australia, Bulgaria, Byelorussian S.S.R., Canada, Czechoslovakia, Denmark, France, Ireland, Italy, Japan, Netherlands, Portugal, Romania, South Africa, Spain, Ukramian S.S.R., U.S.S.R., United Kingdom, Umited States, and Upper Volta. Mexico, the Philippines, and Poland sent letters referring to views previously expressed in the General Assembly. Certain Expenses of the United Nations, supra note 212, at 153-54.

214 During the oral proceedings the Court was addressed by agents of Australia, Canada, Ireland, Italy, Netherlands, Norway, U.S.S.R., United Kingdom, and United States. Id. at 154. 
its opinion on July $20,1962 .{ }^{215}$

An oversimplification, but nevertheless a useful one, is to say that the argunents in this case involve the following basic issues: (1) Can the General Assembly make binding decisions assessing members for costs of operations that do not constitute mere administration? (2) Does the financial power of the U.N. lie solely in the General Assembly or is it shared by the Security Council which should have acted here? (3) Were UNEF or ONUC operations ultra vires, and if so does this affect the financing question? (4) How should the charter be interpreted?

The first issue poses the distinction, primarily put forth by the French, ${ }^{216}$ between two types of U.N. expenses, "administrative" and "others." Only the former type, it was contended, was embraced by article 17 . Other expenses must be financed by voluntary contributions. The rebuttal to this argument rested on several legs: first, the plain meaning of the words which made no such distinction; ${ }^{217}$ second, ample precedent for payment from assessed funds of peacekeeping and other expenses which were not strictly "administrative"; 218 third, the interpretation by the General Assembly itself that the expenses in question were within article $17 .^{210}$

215 Id. at 151. See generally Hogg, supra note 3.

216 Certain EXPEnSES of THe UNITED Nations-Pleadings, supra note 178 , at 133 . The French Government directed a letter to the Registrar of the Court stating that the French Government would not take part in the examination of the question posed to the Court, and giving the reasons therefor. Among these reasons were the arguments mentioned above. $I d$. at 130-35.

217 Id. at 193-94 (statement of the United States).

218 Id. at 197-99. The French letter cited as precedents instances where nonadninistrative expenses were financed by voluntary contributions, $i d$. at 133 , but this merely proves that the General Assembly could have had a practice of using two different approaches.

219 Id. at 187, 191 (written statement of the United States). See the ONUC resolutions quoted above in the text accompanying note 167 supra. During the San Francisco Conference, in drafting the Umited Nations Charter the question arose of "how and by what organ or organs of the organization should the Charter be interpreted?" During a discussion of this question by Committee IV $/ 2$, it was stated:

[I]t is mevitable that each organ will interpret such parts of the Charter as are applicable to its particular functions. . . . Accordingly, it is not necessary to include in the Charter a provision either authorizing or approving the normal operation of this principle.

... Difficulties may conceivably arise in the event that there should be a difference of opimion among the organs of the Organization concerning the correct interpretation of a provision of the Charter. ... Similarly, it would always he open to the General Assembly or to the Security Council, in appropriate circumstances, to ask the International Court of Justice for an advisory opinion concerning the ineaning of a provision of the Charter. ...

It is to be understood, of course, that if an interpretation made by any organ of the Organization or by a committee of jurists is not generally acceptahle, it will be without binding force. In such circumstances, or in cases where it is desired to establish an authoritative interpretation as a precedent for the future, it may be necessary to embody the interpretation in an amendment to the Charter.

13 U.N.C.I.O. 709 (1945). 
The Court, after carefully analyzing the words of article 17, accepted the rebuttal arguments and concluded that article 17 was not limited to "administrative" expenses. ${ }^{220}$

The second issue, the locus of U.N. financial power, was concluded in favor of the General Assembly. ${ }^{221}$ The Soviet brief, in particular, had argued that even though the ONUC authorizing resolutions were correctly Security Council actions (UNEF was established by the General Assembly and thus totally ultra vires in Soviet eyes), ${ }^{222}$ the Security Council was also responsible under article 48 of the charter ${ }^{223}$ for the implementation, through the use of assistance provided by member States under agreements made pursuant to article $43 ;^{224}$ consequently, General Assembly action was

220 Certain Expenses of the United Nations, supra note 212, at 161.

221 Id. at 165.

222 Certain Expenses of the United Nations-Pleadings, supra note 178, at 270-71 (memorandunı of the U.S.S.R. Government).

223 U.N. CHARTER art. 48:

1. The action required to carry out the decisions of the Security Council for the inaintenance of international peace and security shall be taken by all the Menibers of the Umited Nations or by sone of then, as the Security Council may determine. 2. Such decisions shall be carried out by the Members of the United Nations directly and through their action in the appropriate international agencies of which they are menibers.

224 U.N. CHARTER art. 43:

1. All Members of the United Nations, in order to contribute to the maintenance of international peace and security, undertake to make available to the Security Council, on its call and in accordance with a special agreement or agreements, armed forces, assistance, and facilities, including rights of passage, necessary for the purpose of inaintaining international peace and security.

2. Such agreenient or agreenents shall govern the numbers and types of forces, their degree of readiness and general location, and the nature of the facilities and assistance to be provided.

3. The agreenient or agreements shall be negotiated as soon as possible on the initiative of the Security Council. They shall be concluded between the Security Council and Members or between the Security Council and groups of Menbers and shall be subject to ratification by the signatory states in accordance with their respective constitutional processes.

In his oral statement to the ICJ, the Soviet agent (Mr. Tunkin) argued that ONUC was under the authority of articles $42-46$ of the charter. CERTAIN EXPENSES OF THE UNITED Nations - Pleadnos, supra note 178 , at 401 . The relevant Security Council resolutions authorizing ONUC do not specifically refer to the charter authority under which they are passed. Throughout the Security Council debates on ONUC, however, the Secretary-General nuaintained that the action was not an enforcenient measure under articles 41 and 42 of the charter. See U.N. SECURITY CoUNCII OFF. Rec. 15th year, 887th meeting 10 (S/PV.887) (1960). But see U.N. SECURTTY CouncrI OFF. REc. 15th year, 884th neeting, paras. 22-26 (S/PV.884) (1960), where the Secretary-General stated:

The resolutions of the Security Council of 14 July and 22 July were not explicitly adopted under Chapter VII, but they were passed on the basis of an initiative under Article 99. For that reason I have felt entitled to quote three articles [articles 40,41 , and 49] under Chapter VII, and I repeat what I have already said in this respect: In a perspective which may well be short rather than long, the problen facing the Congo is one of peace or war and not only in the Congo.

See Miller, supra note 3. 
illegal..$^{25}$ The Soviet brief even argued that in ONUC the SecretaryGeneral had acted contrary to the charter by selecting the member States who would be asked to contribute forces, since that task, under article 48, was a Security Council function. ${ }^{228}$ This argument is somewhat inconsistent with the prior position of the U.S.S.R., since it voted favorably (not even abstaining) on the summer 1960 ONUC resolutions, under which the Security Council "commends the Secretary-General for the prompt action he has taken to carry out resolution $\mathrm{S} / 4387$,"222 "confirms the authority given to the Secretary-General by the Security Council,"228 and "declares that the entry of the United Nations Force into... Katanga is necessary .... .220 The Court's reasoning on this issue was alternative: UNEF and ONUC were not "enforcement actions" under chapter VII of the charter and therefore article 43 doesn't apply; and even if UNEF or ONUC were "enforcement actions," article 43 contains no limitation upon the discretion of the Security Council to permit some expense of an action to fall within article 17.230

The third issue as stated above was: Were the UNEF and ONUC actions ultra vires the Organization, and if so does this affect the financing provisions? It was hoped by some States that the Court would not go into the authority for UNEF and ONUC, and the question was apparently phrased to avoid this. The United States brief argued that the rejection of a French amendment to the resolution requesting the opinion ${ }^{281}$ was evidence that the resolution did not put in issue the basic authorization of UNEF and ONUC, but that, in any event, UNEF and ONUC were not ultra vires. ${ }^{222}$ The Court, however, took matters into its own firm hands, stating that the rejection of the French amendment could not constitute a directive to the Court to exclude consideration of whether expenditures were decided on in conformity with the charter (and not just article 17), because: "It is not to be assumed that the General Assembly would thus seek to fetter or hamper the Court in the discharge of its judicial functions;

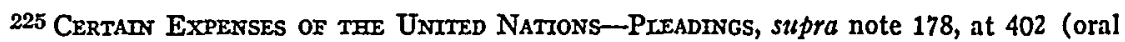
statement of the U.S.S.R.).

226 Id. at 272 (memorandum of the U.S.S.R.).

227 U.N. Security Council Res. S/4405 (879th meeting) (1960).

228 U.N. Security Council Res. S/4426 (886th meeting) (1960).

229 Ibid.

230 Certain Expenses of the United Nations, supra note 212, at 166.

231 The French amendment, U.N. Doc. No. A/L.378 (1961), would have changed the wording of the resolution requesting the advisory opinion from: "Do the expenditures authorized ... [by recited resolutions] constitute 'expenses of the Organization' within the meaning of Article 17 ...." to the following: "Were the expenditures authorized ... [by recited resolutions] decided on in conformity with the Charter and, if so, do they constitute 'expenses of the Organization' within the meaning of Article 17 . ..." CERTAIN EXPENSES OF THE UNITED Nations-PIEAdINGS, supra note 178, at 203-04.

282 Certatn Expenses of the United Nations-Pleadings, supra note 178, at 204-06. 
the Court must have full liberty to consider all relevant data available to it in forming an opinion on a question posed to it for an advisory opinion." 233 The Court said that the expenditures "must be tested by their relationship to the purposes of the United Nations in the sense that if an expenditure were made for a purpose which is not one of the purposes of the United Nations, it could not be considered an 'expense of the Organization." "234

After examining the nature of the UNEF' ${ }^{235}$ and ONUC ${ }^{236}$ operations, the Court concluded that they were within the purposes of the charter. On this issue, the majority of the Court split. Sir Percy Spender (Australia) stated in a separate opinion that he found it unnecessary to express any opinion on the regularity of the resolutions authorizing ONUC and UNEF. ${ }^{237} \mathrm{He}$ was joined in this view by Judge Morelli (Italy). ${ }^{238}$ Since the vote of the Court was nine-to-five, ${ }^{239}$ the question of the underlying validity of the UNEF and ONUC resolutions can be considered unanswered; two majority judges chose not to rule on it, and the five dissenting judges either rendered no opinion on this point ${ }^{240}$ or concluded that the UNEF and ONUC operations were ultra vires. ${ }^{241}$ This same split, however, indicates, apparently, that at least eleven ${ }^{242}$ of the judges felt that to decide the question whether the expenses were those "of the Organization," the Court must necessarily ascertain the validity of the basic operation. Thus, the General Assembly maneuvers to narrowly restrict the Court's attention on the finances question failed. It is interesting to note, however, that the General Assembly's resolution of December 1962 "accepts" the Court opinion "on the question submitted to it." 243

Perhaps of most long range inportance is the fourth issue of how the charter should be interpreted. The United States and other members argued for a broad interpretation. ${ }^{244}$ The United States agent, Abram Chayes, Legal Advisor to the State Department, quoted Chief Justice Marshall's

233 Certain Expenses of the United Nations, supra note 212, at 157.

234 Id. at 167.

235 Id. at 171 .

236 Id. at 177.

237 Id. at 182.

238 Id. at 216.

239 Id. at 179.

240 Id. at 227 (dissenting opinion of President Winiarski, Poland) ; id. at 235 (dissenting opinion of Judge Basdevant, France); id. at 239 (dissenting opinion of Judge Moreno Quintana, Argentina); id. at 288 (dissenting opinion of Judge Bustamante y Rivero, Peru).

241 Id. at 253 (dissenting opinion of Judge Koretsky, U.S.S.R.).

242 The nine judges of the majority, less the two who chose not to rule on UNEF and ONUC validity, plus all but Winiarski of the dissenters.

243 U.N. Gen. Ass. Res. No. 1854 (XVII) (1962). See also U.N. GeN. Ass. Offr. Rec. 17th Sess., 5th Comm. 7 (A/C.5/SR.961) (provisional) (Dec. 19, 1962) (statement of Ambassador Klutznik).

244 Certain Expenses of the Untted Nations-Pleadings, supra note 178, at 203. 
famous phrase in $M c C u l l o c h$ v. Maryland: "In considering this question ... we must never forget, that it is a constitution we are expounding."245 The French letter, however, took precisely the opposite tack, arguing for a strict interpretation: "La Charte est un traité par lequel les États n'ont aliéné leur compétence que dans la stricte mesure où ils y ont consenti."248

The Court's approach to the case, in light of this issue, was particularly interesting. The Court indicated that, in interpreting the charter, it follows the general principles and rules applicable "to the interpretation of treaties, since it has recoguized that the Charter is a multilateral treaty, albeit a treaty having certain special characteristics"; ${ }^{247}$ and that it considers the "structure of the Charter" and relations established by it between the General Assembly and the Security Council, as well as the manner in which the organs concerned "have consistently interpreted the text."248 The Court then proceeded, however, to a minute examination of the words of article $17 .{ }^{249}$ In fact the opinion as a whole is characterized by precise arguments from words of the charter as colored only by consistent practice of U.N. organs. Nowhere does the Court indulge in broad Marshall-like statements about "constitutions," nor does the Court state the argument urged upon it from one of its own prior cases, that "the Organization must be deemed to have those powers which, though not expressly provided in the Charter, are conferred upon it by necessary implication as being essential to the performance of its duties." ${ }^{250}$ From the many arguments presented by able counsel, the Court chose those which were the most technical and the least dependent on implication. It apparently felt no need to rely upon the others in the instant case.

After the Court lianded down its opinion, other activities concerned with U.N. financing could once more resume. The U.S. Congress, which had been dragging its feet in authorizing purchase of U.N. bonds, ${ }^{261}$ partly on the excuse of waiting for the Court opinion, passed the appropriate legislation. ${ }^{252}$ The U.N. Committee on Contributions, after its summer 1962 meeting in Geneva, cautiously reported to the General Assembly that if ONUC and UNEF assessments were included in the calculations, the "contributions unpaid by a few Member States would at present exceed the total amounts for which they were assessed by the General Assembly

245 Id. at 426.

$246 \mathrm{Id}$. at 133.

247 Certain Expenses of the United Nations, supra note 212, at 157.

248 Ibid.

249 E.g., id. at 159.

250 Certadn EXPenses of the United Nations-Pleadings, supra note 178, at 426-27, citing Reparation for Injuries Suffered in Service of the United Nations, [1949] I.C.J. Rep. $174,182$.

251 See Hearings on S. 2768 , supra note 148, at 60.

252 See note 202 supra and accompanying text. 
for 1960 and 1961."253 Agenda item 64 of the seventeenth General Assembly concerned the advisory opinion, and was allocated to Committee Five. ${ }^{254}$ The Fifth Committee discussed draft resolutions on the opinion in early Deceniber 1962, and recommended that the General Assembly "accept" the opinion of the Court ${ }^{255}$-a word studiously ambiguous, but perhaps a shight bit better than alternatives proposed such as "takes note of." ${ }^{256}$ The recommendation was adopted, including a provision re-establishing the Working Group to examine the U.N. financial problem agaim. ${ }^{257}$

Overall, the effect of the Court opinion on U.N. financial problems and on the establishment of sound primciples of international law is not yet clear. The 1961 Working Group of fifteen nations voted on a question almost precisely the same as that addressed to the Court, i.e., were the costs of peacekeeping 'expenses of the Organization' within the nieaming of article 17 of the Charter? On this question six members voted "yes," seven "no," and two reserved opinion. ${ }^{258}$ When the resolution "accepting" the Court

253 U.N. Committee on Contributions, Report, U.N. GEN. Ass. OFF. REc. 17th Sess., Supp. No. 10 , at 4 (A/5210) (1962).

254 Allocation of Agenda Items, U.N. Journad No. 2990, Supp. No. 2 (Sept. 24, 1962), approved by the General Assembly, U.N. GEN. Ass. OFr. Rec. 17th Sess., Plenary (A/PV.1129) (provisional) (Sept. 24, 1962).

255 U.N. Gen. Ass. OFF. Rec. 17th Sess., Annexes, Agenda Item No. 64 (A/5380) (Dec. 18, 1962) ; see discussions in the Fifth Committee, UN. GEN. Ass. OFF. REc. 17th Sess., 5th Comm. (A/C.5/SR.961-69, 971-73) (provisional) (Dec. 3-12, 1962).

Of the nine ICJ advisory opimions requested by the General Assembly, prior to the one in question, all but one had been accepted by a General Assembly resolution, or a General Assembly resolution inviting the Secretary-General or member States to act in accordance with the opmion. In the one exception, the General Assembly nevertheless followed the Court's opimion. See U.N. Gen. Ass. OFF. Rec. 17th Sess.; 5th Comm. 8 (A/C.5/SR.961) (provisional) (1962) (statement of Mr. Klutznik); 5 REPERTORY OF U.N. PrACTICE 40 (U.N. Pub. Sales No. 1955.V.2).

The General Assembly has adopted two resolutions by which it "took note" of advisory opinions. U.N. Gen. Ass. Res. Nos. 187b (III) (1948); 385 (V) (1950). One recommended that each memher of the General Assembly and Security Council should "act in accordance with" the opinion. U.N. Gen. Ass. Res. No. 197a (III) (1948). One "accepted" the advisory opinion and "urged" the governments concerned to give effect to it. U.N. Gen. Ass. Res. No. 449 (V) (1950). One recommended that all the States be guided by the advisory opinion. U.N. Gen. Ass. Res. No. 598 (VI) (1951). Two resolutions stated that the General Assembly "accepts and endorses the advisory opinion." U.N. Gen. Ass. Res. Nos. 934 (X) (1955); 1047 (XI) (1956).

256 U.N. Gen. Ass. Ofr. Rec. 17th Sess., Annexes, Agenda Item No. 64 (A/C.5/L.766) (1962) (amendment proposed by Jordan) ; see Fifth Committee discussion, U.N. GeN. Ass. OFe. REc. 17th Sess., 5th Comm. 2 (A/C.5/SR.973) (provisional) (1962).

257 U.N. Gen. Ass. Res. No. 1854 (XVII) (Dec. 19, 1962).

258 U.N. Gen. Ass. OFr. REc. 16th Sess., Annexes, Agenda Item No. 62, at 3 (A/4971) (1961). The vote was on the question: "the cost of all peace-keeping operations carried out im accordance with mandates given by the appropriate organ must be regarded as expenses of the Organization within the meaning of Article $17 \ldots$. Voting in favor of this statement were Canada, Italy, Japan, Sweden, Umited Kingdom, and the Umited States; voting against were Brazil, Bulgaria, France, Mexico, Nigeria, the United Arah Republic, and the U.S.S.R.; China and India reserved opmion. 
opinion was adopted by the General Assembly, however, of these same 15 members, 11 voted "yes," 3 "no," and 1 abstained. 250 Perhaps this can be deemed encouraging evidence of the influence of the Court. Unfortunately the two largest nations in arrears-the U.S.S.R. and France-still maintain their previous positions. ${ }^{260}$ France has, in addition, refused to pay the portion of the regular budget assessed against her for U.N. bond amortization. ${ }^{261}$

In early February 1963 the reconstituted Working Group met in New York. In calling it into session, the General Assembly resolved that it should:

take into account in its study the criteria for the sharing of the costs of peacekeeping operations mentioned in past resolutions of the General Assembly, giving particular attention to the following:

(a) The references to a special financial responsibility of members of the Security Council as indicated in General Assembly resolutions 1619 (XV) of 21 April 1961 and 1732 (XVI) of 20 December 1961;

(b) Such special factors relating to a particular peacekeeping operation as might be relevant to a variation in the sharing of the costs of the operation;

(c) The degree of economic development of each Member State and whether or not a developing State is in receipt of technical assistance from the United Nations;

(d) The collective financial responsibility of the Members of the United Nations; ${ }^{262}$

Additionally, the General Assembly resolved to convene itself in a special session prior to June 30,1963 , to consider the finances of the organization in light of the report of the Working Group. ${ }^{203}$

${ }^{250}$ See U.N. Gen. Ass. OFF. REC. 17th Sess., 5th Comm. 10 (A/C.5/SR.973) (provisional) (1962). The changes in vote of the members of the Working Group were as follows: Brazil, Mexico, and Nigeria voted "no" in the Working Group, and "yes" on the accepting resolution; China and India voted "reserved" in the Working Group and "yes" on the accepting resolution; the United Arab Republic voted "no" in the Working Group, and abstained on the accepting resolution.

Other switches include the following: Indonesia, which in its reply to the query to governments about financing, U.N. Doc. No. A/AC.104/1/Add.4, at 2-3 (1961), expressed the opinion that the extraordinary expenses of peacekeeping could not be considered "expenses of the Organization"; but Indonesia voted in favor of accepting the World Court opinion. Iraq in its reply to the query, U.N. Doc. No. A/AC.104/1/Add.5, at 2-3 (1961), stated that it did not consider peacekeeping expenses to be within article 17 ; on the resolution accepting the advisory opinion Iraq abstained.

260 973d meeting of the Fifth Cominittee, supra note 259. See also U.N. GEs. Ass. OrF. REc. 17th Sess., Annexes, Agenda Item No. 64 (A/C.5/957) (Dec. 6, 1962) (memorandum of U.S.S.R. concerning financing).

261 New York Times, Jan. 28, 1963, p. 1, col. 5.

262 U.N. Gen. Ass. Res. No. 1854 (XVII) (Dec. 19, 1962).

263 U.N. Gen. Ass. Res. No. 1866 (XVII) (Dec. 20, 1962). 


\section{VII}

\section{REFLECTIONS}

In a remarkable document issued just before his death, the late Dag Hammarskjold sharply posed the existing dichotomy in opinions about the U.N., as follows:

On the one side, it has in various ways become clear that certain Members conceive of the Organization as a static conference machmery for resolving conflicts of interests and ideologies with a view to peaceful co-existence, within the Charter, to be served by a Secretariat which is to be regarded not as fully internationalized but as representing within its ranks those very interests and ideologies.

Other Members have inade it clear that they conceive of the Organization primarily as a dynamic instrument of Governments through which they, jointly and for the same purpose, should seek such reconciliation but through which they should also try to develop forms of executive action, undertaken on belialf of all Members, and aiming at forestalling conflicts and resolving them, once they have arisen, by appropriate diplomatic or political ineans, in a spirit of objectivity and in implementation of the principles and purposes of the Charter. ${ }^{264}$

It is this dichotomy, plus the question of equal voting power for vastly unequal power and contribution, due in part, ironically, to the abuse of the veto in the Security Council and the resultant shift of power to the General Assembly, that are the fundamental problems of the United Nations "financial" crisis. ${ }^{265}$ If this premise be valid, then it follows that attempts to solve the crisis by financial means will have at best a palliative effect, without solving the basic illness. The bond issue is one example. It has postponed the day of reckoning, but with continued U.S.S.R. and French intransigence, the basic problems are unresolved.

The same can be said about proposals for sanctions for nonpayment. The weakness of article 19 sanctions has already been noted. ${ }^{266}$ More stringent sanctions might well be attempted through a General Assembly vote, although there are two formidable hurdles: (1) the unpopularity of such measures in a General Assembly where many members are themselves delinquent; ${ }^{267}$ and (2) a possible charter objection. ${ }^{268}$ If these hurdles could

264 Introduction to the Annual Report of the Secretary-General on the Work of the Organization, 16 June 1960-15 June 1961, U.N. GEN. Ass. OFr. REc. 16th Sess., Supp. No. 1A, at 1 (A/4800/Add.1) (1961).

205 See quotation from the House Report on the U.N. Bond Bill, supra note 185.

266 See text accompanying note 190 supra.

267 As of December 31, 1962, almost seventy member States of the U.N. were still in arrears. See Statement on the Collection of Contributions as at 31 December 1962, U.N. Doc. No. ST/ADM/SER.B/168 (1963).

208 It can be argued that since article 19 specified a sanction for nonpayment of contributions, all other sanctions are ultra vires, under the general principle "Expressio unius est exclusio 
be overcome, the application of interest to arrears, ${ }^{260}$ or a provision denying or setting-off any U.N. payments for economic aid, reimbursement for travel expenses, etc., to members in arrears, miglit have some effect. In addition there is the intriguing prospect of a suit in the World Court by one Organization member against another for arrears, as suggested by a writer as long ago as $1942 .^{270}$

But it is doubtful that more stringent sanctions are in the interests of the United States, and obviously they are not in the interests of some other large powers. The day may indeed come when the U.S. will feel impelled to break its treaty obligation and refuse to pay an assessment that would support an irresponsibly conceived activity, voted by States whose financial involvement or other interests were minimal. ${ }^{271}$

Various other suggestions to improve U.N. finances are subject to similar criticism. For instance, proposals have been made to establish some independent sources of income for the U.N., such as special taxes or revenues from new undersea or Antarctic resources. These measures would have the effect of strengthening U.N. power without adding an iota of control over U.N. actions to the large nations. Consequently, it is doubtful that they would be acceptable to other powers or even in the interests of the United States. ${ }^{272}$ An identical criticism applies to proposals to establish a large "peace and security fund" in anticipation of any sudden need by the Organization.

All these possibilities fail to reach the fundamental problems. How can these problems be approached? One possibility often suggested is a charter amendment. However, the two-thirds vote and the veto power of the five permanent Security Council members pose almost insurmountable obsta-

alterius." The League of Nations also had problems about arrears. In a 1927 report, the Secretary-General expressed his opinion that, with regard to possible sanctions for nonpayment, "it appears certain that the strictly legal rights (including, for example, the rigbt to vote in the Assembly and eligibility for membership of the Council) which the state derives from membership in the League cannot suffer any diminution as a result of default in payment of contributions." Aufricht, Gume to League of Nations Publications 99 (1951).

260 See Jenks, Some Legal Aspects of the Financing of International Institutions, 28 TransACT. Grot. Soc'y 87, 106 (1943).

$270 \mathrm{Id}$. at 113. Such a suit would presumably have to be brought by a member who has accepted compulsory jurisdiction of the International Court of Justice under article 36 against another State which has accepted the same jurisdiction. The Organization itself, not being a "State," would not have standing to sue in such a contentious proceeding. Since the Soviet bloc has not accepted the compulsory jurisdiction of the International Court of Justice, it would not be liable to that kind of suit. The problem still remains, of course, of how the judgment in such a suit would be enforced.

271 Hogg, supra note 3, at 1263.

272 See Hearings on S. 2768, sutpra note 148, at 83 (testimony of George Ball, Undersecretary of State). Some proposals are discussed critically in NicHors, op. cit. supra note 3, and Stoessinger, supra note 3 , at 64 . 
cles to this route. ${ }^{273}$ Furthermore, that solution is relatively inflexible for the future. Clearly the constitutional nature of the U.N. Charter is not settled, nor is the scope of U.N. activity. Even should some consensus be reached on a charter amendment, as time went on the amended version could prove rigid and unworkable.

Recognizing the hazards of recommendations for a seemingly insoluble problem, it would seem, nevertheless, that the greatest hope for a sound solution lies in flexible reforms of structure and procedure that can be carried out by the General Assembly without a charter amendment. For instance, why not provide for a change in General Assembly rules to the effect that, first, the six largest contributors have a reserved place and added voting weight on the $A C A B Q$, and second, that $A C A B Q$ recommendations within an enlarged area of competence can be overruled by the Fifth Committee only by a two-thirds vote. This would (1) avoid a veto power; (2) give great powers a greater voice; (3) avoid changing the principle of equality of voting in the General Assembly; and (4) allow flexible future adjustment of the structure as the U.N.'s place in the world becomes crystallized.

It would seem that U.S. diplomatic efforts should reap greater long run rewards by focusing on these fundamental problems of the U.N. rather than persistently trying to reduce U.S. contributions to the U.N. In short, the U.N. does not have a financial crisis, but a political and constitutional crisis that should be dealt with as such.

273 U.N. CharTer art. 108. If, instead of attempting to have a general charter revision, attentions were focused on just one amendment of the charter at a time, it is more probable that an amendment could be drafted which would succeed. 


\section{APPENDIX}

\section{Calculation of U.N. Assessment Scajes}

The method used by the Committee on Contributions to calculate U.N. assessment scales and recommended to the General Assembly is outlined in a 1961 report of the committee.1 This report does not, however, include all the mathematical details. The following is a description of this calculation, drawn from the report, with some ideas as to how the ambiguities in that report are or could be resolved. (Where the description below is not completely supported by the committee report, it is so indicated, usually by the word "assumedly.") Based on this description of the calculation, the computation of U.N. assessment scales was programmed for a computer, and used to produce several hundred scales on a variety of assumptions. Several of the more interesting of these scales are reproduced below. Since the data used by Committee on Contributions for calculation of the U.N. assessment scales is not available publicly, the scales below, based on published data, differ significantly from the true U.N. assessment scale. Yet they do give some indications of the probable relationships between the different countries.

\section{A. DESCRIPTION OF CAICULATION}

The assessment scale is calculated from two figures for each country-a national income figure and a population figure. The data used for the current U.N. scale was an average national income figure for 1957,1958 , and 1959, and a mid-1958 population figure. In mid-1961, when the committee calculated the present scale, these were considered the best and most complete figures available. The calculation proceeds as follows:

1. A dollar national income figure is obtained by using exchange rates. Figures of some of the Socialist countries were adjusted upward to compensate for the difference in the methods of calculation of national income statistics for those countries.

2. The national income of each country with a per capita national income less than $\$ 1,000$ per year, was adjusted downward by a formula described by the committee as follows:

A deduction is made from the national income of each country with a per caput income equivalent to less than $\$ 1,000$. The difference between $\$ 1,000$ and a country's per caput income is expressed as a percentage, and 50 per cent of that percentage is deducted from the country's national income for the purpose of arriving at the assessment. Thus, since the allowance is progressive, the lower the per caput income the more nearly the percentage deduction approaches 50 per cent of the national income, while a country with a per caput income of $\$ 1,000$ or over received no reduction at all.

Assuming that "percentage," as used by the committee means percentage of $\$ 1000$, this adjustment can be expressed by the following formula:

$$
\text { Adjusted National Income }(\mathrm{NI})=\mathrm{NI}-\mathrm{NI} \times .50 \times\left(\frac{1000-(\mathrm{NI} / \text { Population }}{1000}\right)
$$

3. Assumedly, each member's adjusted national income is divided by the sum of the adjusted (where applicable) national incomes of all the members. The quotient can be called the "raw percentage."

$$
\text { Raw } \%=\frac{\text { NI (adjusted) }}{\text { sum of all NI's }}
$$

4. Each country whose raw percentage exceeds the "ceiling" or maximum contribution is assigued the ceiling as its percentage. By General Assembly resolution the maximum is $331 / 3 \%$, with a "principle" that no country should pay more than $30 \% .^{2}$ The committee decided that this mandate should bring the maximum in the current scale to $32.02 \%$, and set the U.S. percentage at this figure.

5. No country was assessed below the "fioor" of $0.04 \%$, and each country whose raw percentage was less than this amount was raised to $0.04 \%$.

6. Some countries, for special reasons, may have their percentages adjusted downward. The committee reported that in the current scale the Congo (Leopoldville) and Chile were adjusted downward for special reasons.

7. The apphication of the ceiling, the floor, and the special adjustments results in a total

1 U.N. Gen. Ass. OfF. Rec. 17th Sess., Supp. No. 10 (A/4775) (1961).

2 U.N. Gen. Ass. Res. No. 1137 (XII) (1957). 
percentage not equalling $100 \%$. If the ceiling or a special adjustment reduces the percentage of any country, there results a "percentage gap" between the percentage total and $100 \%$. The floor, if it raises the percentage of any countries, would reduce some of this gap, conceivably even raising the total percentage to over $100 \%$. In either event it is a reasonable assumption (not described in the committee's report) that this gap or discrepancy is at this point redistributed among the other countries unaffected by either ceilings, floors, or special adjustments. This redistribution can reasonably be made on the basis of each country assuming a portion of the discrepancy equal to its raw percentage divided by the total raw percentages of unaffected countries, as follows:

$$
\text { Adjusted Raw } \%=\text { Raw } \%+\left(\text { Discrepancy } \% \times \frac{\text { Raw } \%}{\text { Total Raw \% }}\right)
$$

(Total Raw $\%=$ total of countries unaffected by the ceiling, floor, or special adjustment.) This will yield a total scale of $100 \%$.

8. Per capita ceiling principle: The committee, following its terns of reference, compares the per capita contribution (which can at this point be expressed as its adjusted raw percentage divided by population) of each country not at the floor or ceiling, or specially adjusted, with the per capita contribution of the largest contributor (the U.S.). If a country's per capita contribution exceeds that of the largest contributor, its percentage is lowered to the point where its per capita contribution equals that of the largest contributor. The committee reports that only Canada was affected by this principle in the current scale.

9. The operation of the per capita ceiling principle may result in another discrepancy between the total scale and $100 \%$, so the discrepancy could, assumedly, be redistributed in the same manner as in paragraph 7 above.

10. There may be some final small adjustments made on some percentages, which cancel each other. After this a final percentage for each country results, with a total of $100 \%$.

11. When nations are admitted to the U.N. after a scale is approved, they are generally assessed a percentage that is added to the total of $100 \%$, yielding a total percentage slightly above $100 \%$.

\section{B. SOME SCALES CALCULATED}

Using a computer, programmed to follow the steps outlined above (omitting discretionary steps Nos. 6 and 10), but allowing for changes in the ceiling, floor, and the adjustment for low per capita, as well as the method of converting local currencies to dollars, a number of scales have been calculated. The basic source for the data used is explaimed below. Since this data is not complete for all members of the UN., however, it was necessary to search elsewhere for data for at least those missing countries which figured prominently in the scale. By this ineans data has been assembled for 59 of the 110 U.N. members (and several noninembers), with present U.N. percentages totalling 97.32 percent. The remaining 2.68 percent of the scale is ignored. The countries comprising this "ignored" aunount (those with " 0 " in either data column) are "frozen" at their present U.N. percentage, and the calculations are adjusted at a necessary point to account for this.

In some cases rather arbitrary figures had to be estimated or assumed, because of the great variance in available figures. This is especially true for the national income of the U.S.S.R. Consequently, the scales which are calculated can by no means be taken as recommended or justifiable U.N. assessment scales. Only the relationship between the percentage of a given country in one scale, with its percentage in a different scale using different assumptions, is meaningful.

Scale No. 1 gives the result of the assessment scale calculation using the data set forth for the 100 countries presently included within the $100 \%$ of the current scales. If the data were identical to that used by the U.N., Scale No. 1 would closely approximate the present U.N. scale (set out to the left of Scale No. 1 for ease of comparison). Starting upon this basis, the following variations in the calculations are made:

Scale No. 2: No adjustment is made for low per capita national income, and no ceiling or floor is applied. This scale represents simply each State's national income, divided by the sum of the national incomes of $100 \mathrm{UN}$. members.

Scale No. 3: This is the same as Scale No. 2, except that an adjustment has been made (see step No. 2 of the calculation explanation above) for low per capita national income.

Scale No. 4: This is the same as Scale No. 3, except that the national income figures for certain Western European nations is the local currency national income converted to dollars 
by use of "purchasing power equivalents" 3 (not shown) instead of exchange rates. These figures are used in the table for Belgium, Denmark, France, Germany, Italy, Netherlands, Norway, and the Umited Kingdom.

Scale No. 5: This is similar to Scale No. 3, except that the adjustment for low per capita income is unade with the number 400 instead of 1,000 , and the number 0.70 instead of 0.50 , in the formula. This scale should be compared closely with Scale No. 3. It will be seen that, in effect, the more industrialized countries, which have per capita incomes significantly below $\$ 1,000$ but over $\$ 400$ (e.g., Italy, $\$ 505$ ), have been increased in the scale, while nations with per capita incomes significantly below $\$ 400$ have been decreased (e.g., China, $\$ 81$; India, $\$ 69$ ). This scale reduces lower income countries by a greater amount, but reduces fewer countries than the adjustment presently made under the U.N. scale.

Scale No. 6: This is the same as Scale No. 3, except that instead of 100 members, this scale is based on the 114 members shown, assigning $0.04 \%$ (floor) to the 10 new U.N. nnembers ${ }^{4}$ and using national income figures as shown for several other nations ${ }^{5}$ which may one day be U.N. unembers.

Scale No. 7: This is the same as Scale No. 3, except that using growth rates for national income and population, these figures are projected ten years (to 1970) and used to calculate the U.N. assessment scale. No meaningful growth rate figures were found for China, Sudan, and Ireland, so these countries were frozen at their present U.N. scale percentage. Thus this scale is calculated on the basis of data for countries totaling $92.54 \%$ of the scale. It will be seen that the U.S.S.R. percentage has grown, and the U.S. percentage has declined, although the U.S. percentage is still above the current ceiling.

${ }^{3}$ Purchasing power equivalents give a more realistic comparison of national income, and are derived and explained in Gimbert, Comparative National Products and Price Levels (1955). The equivalents used were derived for the year 1955. While out of date, they are the only available ones found.

4 Countries nos. 101-10 in the tabular scale infra.

5 Countries nos. 111-13 in the tabular scale infra. 
DATA INPUT

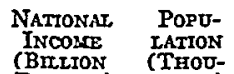
Countzy

1. Afghanistan

2. Albania

3. Argentina

4. Australia

5. Austria

6. Belgium

7. Bolivia

8. Brazil

9. Bulgaria

10. Burma

11. Cambodia

12. Cameroun

13. Canada

14. Cent. African Rep.

15. Ceylon

16. Chad

17. Chile

18. China

19. Colombia

20. Congo (Brazz.)

21. Congo (Leop.)

22. Costa Rica

23. Cuba

24. Cyprus

25. Czechoslovakia

26. Daliomey

27. Denmark

28. Dominican Rep.

29. Ecuador

30. El Salvador

31. Ethiopia

32. Finland

33. France

34. Gabon

35. Ghana

36. Greece

37. Guatemala

38. Guinea

39. Haiti

40. Honduras

41. Hungary

42. Iceland

43. India

44. Indonesia

45. Iran

46. Iraq

47. Ireland

48. Israel

49. Italy

50. Ivory Coast

51. Japan

52. Jordan

53. Laos

54. Lebanon

55. Liberia

56. Libya

57. Luxembourg
(BILLION
DOLLARS) (THOO

0

0

$7.512 \quad 20006$

$4.561 \quad 7081$

$8.946 \quad 9153$

$\begin{array}{lr}0 & 3462 \\ 9.151 & 65743\end{array}$

$3.031 \quad 7867$

$1.033 \quad 20662$

$0 \quad 4952$

$0 \quad 4097$

$27.596 \quad 17814$

$0 \quad 1227$

$1.188 \quad 9896$

$\begin{array}{ll}0 & 2639 \\ 3.687 & 7340\end{array}$

$57.132 \quad 706863$

$3.579 \quad 14132$
0

$\begin{array}{lr}0 & 795 \\ 0 & 14150\end{array}$

$0.400 \quad 1171$

$2.391 \quad 6797$

$0 \quad 563$

$10.622 \quad 13654$

$0 \quad 1934$

$4.761 \quad 4581$

$0 \quad 2994$

$0.779 \quad 4317$

$0.457 \quad 2612$

0 20000

$3.611 \quad 4449$

$43.467 \quad 45542$

$0 \quad 440$

$0 \quad 6691$

$2.657 \quad 8327$

$0.588 \quad 3765$

$0 \quad 3000$

$0 \quad 3505$

$0.334 \quad 1883$

$5.863 \quad 9999$

$0.138 \quad 176$

$4.651 \quad 92600$

0 20182

$\begin{array}{ll}0 & 7085\end{array}$

$1.481 \quad 2834$

$1.913 \quad 2114$

$24.950 \quad 49361$

$0 \quad 3230$

$31.778 \quad 93200$

$0 \quad 1695$

$0 \quad 1805$

$0 \quad 1646$

$0 \quad 1290$

$0 \quad 1195$

$0.370 \quad 314$
$12.779 \quad 10275$

$29.820 \quad 432567$
PRESENT

U.N.

0.05

0.04

1.01

1.66

0.45

1.20

0.04

1.03

0.20

0.07

0.04

0.04

3.12

0.04

0.09

0.04

0.26

4.57

0.26

0.04

0.07

0.04

0.22

0.04

1.17

0.04

0.58

0.05

0.06

0.04

0.05

0.37

5.94

0.04

0.09

0.23

0.05

0.04

0.04

0.04

0.56

0.04

2.03

0.45

0.20

0.09

0.14

0.15

2.24

0.04

2.27

0.04

0.04

0.05

0.04

0.04

0.05
SCALES CALCULATED

$\begin{array}{lllllll}1 & 2 & 3 & 4 & 5 & 6\end{array}$

$\begin{array}{lllllll}0.05 & 0.05 & 0.05 & 0.05 & 0.05 & 0.05 & 0.05\end{array}$

$\begin{array}{lllllll}0.04 & 0.04 & 0.04 & 0.04 & 0.04 & 0.04 & 0.04\end{array}$

$\begin{array}{lllllll}0.68 & 0.70 & 0.55 & 0.50 & 0.73 & 0.51 & 0.37\end{array}$

$\begin{array}{lllllll}1.67 & 1.20 & 1.36 & 1.24 & 1.30 & 1.27 & 1.32\end{array}$

$\begin{array}{lllllll}0.49 & 0.43 & 0.40 & 0.36 & 0.46 & 0.37 & 0.48\end{array}$

$\begin{array}{lllllll}1.16 & 0.84 & 0.94 & 1.15 & 0.91 & 0.88 & 0.69\end{array}$

$\begin{array}{lllllll}0.04 & 0.04 & 0.04 & 0.04 & 0.04 & 0.04 & 0.04\end{array}$

$\begin{array}{lllllll}0.68 & 0.86 & 0.55 & 0.50 & 0.50 & 0.52 & 0.56\end{array}$

$\begin{array}{lllllll}0.27 & 0.28 & 0.22 & 0.20 & 0.30 & 0.21 & 0.35\end{array}$

$\begin{array}{lllllll}0.07 & 0.10 & 0.06 & 0.05 & 0.04 & 0.05 & 0.05\end{array}$

$\begin{array}{llllllll}0.04 & 0.04 & 0.04 & 0.04 & 0.04 & 0.04 & 0.04\end{array}$

$\begin{array}{lllllll}0.04 & 0.04 & 0.04 & 0.04 & 0.04 & 0.04 & 0.04\end{array}$

$\begin{array}{lllllll}3.16 & 2.58 & 2.93 & 2.67 & 2.80 & 2.74 & 2.37\end{array}$

$\begin{array}{lllllll}0.04 & 0.04 & 0.04 & 0.04 & 0.04 & 0.04 & 0.04\end{array}$

$\begin{array}{llllllll}0.09 & 0.11 & 0.07 & 0.06 & 0.06 & 0.07 & 0.05\end{array}$

$\begin{array}{lllllll}0.04 & 0.04 & 0.04 & 0.04 & 0.04 & 0.04 & 0.04\end{array}$

$\begin{array}{lllllll}0.36 & 0.34 & 0.29 & 0.27 & 0.37 & 0.28 & 0.25\end{array}$

$\begin{array}{lllllll}4.04 & 5.34 & 3.28 & 2.99 & 2.56 & 3.07 & 4.57\end{array}$

$\begin{array}{lllllll}0.29 & 0.33 & 0.24 & 0.22 & 0.27 & 0.22 & 0.22\end{array}$

$\begin{array}{llllllll}0.04 & 0.04 & 0.04 & 0.04 & 0.04 & 0.04 & 0.04\end{array}$

$\begin{array}{lllllll}0.07 & 0.07 & 0.07 & 0.07 & 0.07 & 0.07 & 0.07\end{array}$

$\begin{array}{lllllll}0.04 & 0.04 & 0.03 & 0.03 & 0.04 & 0.03 & 0.03\end{array}$

$\begin{array}{lllllll}0.21 & 0.22 & 0.17 & 0.16 & 0.22 & 0.16 & 0.15\end{array}$

$\begin{array}{lllllll}0.04 & 0.04 & 0.04 & 0.04 & 0.04 & 0.04 & 0.04\end{array}$

$\begin{array}{lllllll}1.24 & 0.99 & 1.00 & 0.91 & 1.08 & 0.94 & 1.27\end{array}$

$\begin{array}{lllllll}0.04 & 0.04 & 0.04 & 0.04 & 0.04 & 0.04 & 0.04\end{array}$

$\begin{array}{lllllll}0.62 & 0.45 & 0.51 & 0.70 & 0.48 & 0.47 & 0.39\end{array}$

$\begin{array}{lllllll}0.05 & 0.05 & 0.05 & 0.05 & 0.05 & 0.05 & 0.05\end{array}$

$\begin{array}{llllllll}0.06 & 0.07 & 0.05 & 0.04 & 0.05 & 0.05 & 0.04\end{array}$

$\begin{array}{lllllll}0.04 & 0.04 & 0.03 & 0.03 & 0.03 & 0.03 & 0.03\end{array}$

$\begin{array}{lllllll}0.05 & 0.05 & 0.05 & 0.05 & 0.05 & 0.05 & 0.05\end{array}$

$\begin{array}{lllllll}0.43 & 0.34 & 0.35 & 0.32 & 0.37 & 0.33 & 0.32\end{array}$

$\begin{array}{lllllll}5.56 & 4.07 & 4.52 & 7.23 & 4.41 & 4.22 & 3.92\end{array}$

$\begin{array}{lllllll}0.04 & 0.04 & 0.04 & 0.04 & 0.04 & 0.04 & 0.04\end{array}$

$\begin{array}{lllllll}0.09 & 0.09 & 0.09 & 0.09 & 0.09 & 0.09 & 0.09\end{array}$

$\begin{array}{lllllll}0.23 & 0.25 & 0.19 & 0.17 & 0.23 & 0.17 & 0.22\end{array}$

$\begin{array}{lllllll}0.04 & 0.05 & 0.04 & 0.03 & 0.03 & 0.03 & 0.03\end{array}$

$\begin{array}{lllllll}0.04 & 0.04 & 0.04 & 0.04 & 0.04 & 0.04 & 0.04\end{array}$

$\begin{array}{lllllll}0.04 & 0.04 & 0.04 & 0.04 & 0.04 & 0.04 & 0.04\end{array}$

$\begin{array}{lllllll}0.04 & 0.03 & 0.02 & 0.02 & 0.02 & 0.02 & 0.02\end{array}$

$\begin{array}{lllllll}0.61 & 0.55 & 0.49 & 0.45 & 0.59 & 0.46 & 0.59\end{array}$

$\begin{array}{lllllll}0.04 & 0.01 & 0.01 & 0.01 & 0.01 & 0.01 & 0.01\end{array}$

$\begin{array}{lllllll}2.09 & 2.79 & 1.69 & 1.54 & 1.27 & 1.59 & 1.33\end{array}$

$\begin{array}{lllllll}0.32 & 0.43 & 0.26 & 0.24 & 0.18 & 0.24 & 0.22\end{array}$

$\begin{array}{lllllll}0.20 & 0.20 & 0.20 & 0.20 & 0.20 & 0.20 & 0.20\end{array}$

$\begin{array}{lllllll}0.09 & 0.09 & 0.09 & 0.09 & 0.09 & 0.09 & 0.09\end{array}$

$\begin{array}{lllllll}0.15 & 0.14 & 0.12 & 0.11 & 0.15 & 0.11 & 0.14\end{array}$

$\begin{array}{lllllll}0.24 & 0.18 & 0.19 & 0.18 & 0.19 & 0.18 & 0.27\end{array}$

$\begin{array}{lllllll}2.46 & 2.33 & 2.00 & 4.33 & 2.53 & 1.87 & 2.38\end{array}$

$\begin{array}{lllllll}0.04 & 0.04 & 0.04 & 0.04 & 0.04 & 0.04 & 0.04\end{array}$

$\begin{array}{lllllll}2.79 & 2.97 & 2.27 & 2.06 & 2.89 & 2.12 & 3.55\end{array}$

$\begin{array}{lllllll}0.04 & 0.04 & 0.04 & 0.04 & 0.04 & 0.04 & 0.04\end{array}$

$\begin{array}{lllllll}0.04 & 0.04 & 0.04 & 0.04 & 0.04 & 0.04 & 0.04\end{array}$

$\begin{array}{lllllll}0.05 & 0.05 & 0.05 & 0.05 & 0.05 & 0.05 & 0.05\end{array}$

$\begin{array}{lllllll}0.04 & 0.04 & 0.04 & 0.04 & 0.04 & 0.04 & 0.04\end{array}$

$\begin{array}{lllllll}0.04 & 0.04 & 0.04 & 0.04 & 0.04 & 0.04 & 0.04\end{array}$

$\begin{array}{llllllll}0.04 & 0.03 & 0.04 & 0.04 & 0.04 & 0.04 & 0.03\end{array}$ 
DATA INPUT

National Popu-

CoUnIRY

58. Madagascar

59. Malaya

60. Mali

61. Mexico

62. Morocco

63. Nepal

64. Netherlands

65. New Zealand

66. Nicaragua

67. Niger

68. Nigeria

69. Norway

70. Pakistan

71. Panama

72. Paraguay

73. Peru

74. Philippines

75. Poland

76. Portugal

77. Romania

78. Saudi Arabia

79. Senegal

80. Somalia

81. Spain

82. Sudan

83. Sweden

84. Syrian Arab Rep.

85. Thailand

86. Togo

87. Tunisia

88. Turkey

89. Union So. Africa

90. U.S.S.R.

91. United Arab. Rep.

92. United Kingdom

93. United States

94. Upper Volta

95. Uruguay

96. Venezuela

97. Yemen

98. Yugoslavia

99. Byelorussian S.S.R.

100. Ukrainian S.S.R.

101. Mauritania

102. Mongolia

103. Sierra Leone

104. Tanganyika

105. Algeria

106. Burundi

107. Jamaica

108. Rwanda

109. Trinidad-Tobago

110. Uganda

111. W. Ger. Fed. Rep.

112. Korea Rep.

113. Switzerland

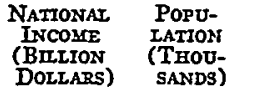

Present

$0 \quad 5393$

$0 \quad 6909$

$0 \quad 4100$

$9.608 \quad 34923$

$1.531 \quad 11626$

$0 \quad 9180$

$9.161 \quad 11480$

$3.086 \quad 2372$

$\begin{array}{ll}0 & 1477 \\ 0 & 2870\end{array}$

$\begin{array}{lr}0 & 2870 \\ 0 & 35091\end{array}$

$3.443 \quad 3586$

$4.747 \quad 92727$

$0.366 \quad 1055$

$0.187 \quad 1768$

$1.578 \quad 10857$

$5.246 \quad 27500$

$14.860 \quad 29703$

$\begin{array}{lr}2.027 & 8921 \\ 0 & 18403\end{array}$

$0 \quad 18403$

$\begin{array}{rr}0 & 0 \\ 0 & 2973\end{array}$

$\begin{array}{ll}0 & 2973 \\ 0 & 2030\end{array}$

$7.439 \quad 30128$

$1.005 \quad 11770$

$10.055 \quad 7480$

$0 \quad 4555$

$2.190 \quad 25520$

$0 \quad 1440$

$0 \quad 4168$

$4.983 \quad 27561$

$6.275 \quad 15780$

$157.000 \quad 214400$

$3.159 \quad 25929$

$56.857 \quad 52539$

$413.358 \quad 180670$

$0 \quad 3635$

$\begin{array}{ll}0 & 2827 \\ 5.894 & 7365\end{array}$

$0 \quad 5000$

$5.372 \quad 18402$

$0 \quad 8226$

$0 \quad 43091$

$0 \quad 727$

$0 \quad 937$

$0 \quad 2450$

$\begin{array}{rr}0 & 9239 \\ 0 & 11020\end{array}$

0 2224

0.5741621

$0 \quad 2665$

$0 \quad 844$

$0 \quad 6677$

$51.266 \quad 53373$

$2.732 \quad 24665$

7.321

5351

0

0

0.04
SCALES CALCULATED

\begin{tabular}{rrrrrrrr}
$\begin{array}{c}\text { PRESEN } \\
\text { U.N. }\end{array}$ & \multicolumn{1}{c}{1} & \multicolumn{1}{c}{2} & \multicolumn{1}{c}{3} & \multicolumn{1}{c}{4} & \multicolumn{1}{c}{5} & 6 & 7 \\
ScAIE & & & & & & & \\
0.04 & 0.04 & 0.04 & 0.04 & 0.04 & 0.04 & 0.04 & 0.04 \\
0.13 & 0.13 & 0.13 & 0.13 & 0.13 & 0.13 & 0.13 & 0.13 \\
0.04 & 0.04 & 0.04 & 0.04 & 0.04 & 0.04 & 0.04 & 0.04 \\
0.74 & 0.80 & 0.90 & 0.65 & 0.59 & 0.76 & 0.61 & 0.95 \\
0.14 & 0.11 & 0.14 & 0.09 & 0.08 & 0.08 & 0.09 & 0.06 \\
0.04 & 0.04 & 0.04 & 0.04 & 0.04 & 0.04 & 0.04 & 0.04 \\
1.01 & 1.08 & 0.86 & 0.88 & 1.55 & 0.93 & 0.82 & 0.86 \\
0.41 & 0.40 & 0.29 & 0.33 & 0.30 & 0.31 & 0.31 & 0.32 \\
0.04 & 0.04 & 0.04 & 0.04 & 0.04 & 0.04 & 0.04 & 0.04 \\
0.04 & 0.04 & 0.04 & 0.04 & 0.04 & 0.04 & 0.04 & 0.04 \\
0.21 & 0.21 & 0.21 & 0.21 & 0.21 & 0.21 & 0.21 & 0.21 \\
0.45 & 0.44 & 0.32 & 0.36 & 0.50 & 0.35 & 0.34 & 0.28 \\
0.42 & 0.33 & 0.44 & 0.27 & 0.24 & 0.19 & 0.25 & 0.19 \\
0.04 & 0.04 & 0.03 & 0.03 & 0.02 & 0.03 & 0.02 & 0.02 \\
0.04 & 0.04 & 0.02 & 0.01 & 0.01 & 0.01 & 0.01 & 0.01 \\
0.10 & 0.12 & 0.15 & 0.10 & 0.09 & 0.09 & 0.09 & 0.07 \\
0.40 & 0.41 & 0.49 & 0.33 & 0.30 & 0.34 & 0.31 & 0.34 \\
1.28 & 1.46 & 1.39 & 1.19 & 1.08 & 1.51 & 1.11 & 1.90 \\
0.16 & 0.16 & 0.19 & 0.13 & 0.12 & 0.14 & 0.12 & 0.12 \\
0.32 & 0.32 & 0.32 & 0.32 & 0.32 & 0.32 & 0.32 & 0.32 \\
0.07 & 0.07 & 0.07 & 0.07 & 0.07 & 0.07 & 0.07 & 0.07 \\
0.05 & 0.05 & 0.05 & 0.05 & 0.05 & 0.05 & 0.05 & 0.05 \\
0.04 & 0.04 & 0.04 & 0.04 & 0.04 & 0.04 & 0.04 & 0.04 \\
0.86 & 0.61 & 0.70 & 0.49 & 0.45 & 0.55 & 0.46 & 0.51 \\
0.07 & 0.07 & 0.09 & 0.06 & 0.05 & 0.05 & 0.05 & 0.07 \\
1.30 & 1.32 & 0.94 & 1.07 & 0.97 & 1.02 & 1.00 & 0.84 \\
0.05 & 0.05 & 0.05 & 0.05 & 0.05 & 0.05 & 0.05 & 0.05 \\
0.16 & 0.16 & 0.20 & 0.13 & 0.11 & 0.10 & 0.12 & 0.11 \\
0.04 & 0.04 & 0.04 & 0.04 & 0.04 & 0.04 & 0.04 & 0.04 \\
0.05 & 0.05 & 0.05 & 0.05 & 0.05 & 0.05 & 0.05 & 0.05 \\
0.40 & 0.38 & 0.47 & 0.31 & 0.28 & 0.31 & 0.29 & 0.33 \\
0.53 & 0.57 & 0.59 & 0.47 & 0.42 & 0.63 & 0.44 & 0.43 \\
17.47 & 17.79 & 14.68 & 14.46 & 13.15 & 15.92 & 13.52 & 25.21 \\
0.25 & 0.23 & 0.30 & 0.19 & 0.17 & 0.16 & 0.18 & 0.17 \\
7.58 & 7.44 & 5.32 & 6.04 & 7.22 & 5.76 & 5.65 & 4.39 \\
32.02 & 32.02 & 38.66 & 43.95 & 39.96 & 41.91 & 41.11 & 32.53 \\
0.04 & 0.04 & 0.04 & 0.04 & 0.04 & 0.04 & 0.04 & 0.04 \\
0.11 & 0.11 & 0.11 & 0.11 & 0.11 & 0.11 & 0.11 & 0.11 \\
0.52 & 0.69 & 0.55 & 0.56 & 0.51 & 0.60 & 0.53 & 0.75 \\
0.04 & 0.04 & 0.04 & 0.04 & 0.04 & 0.04 & 0.04 & 0.04 \\
0.38 & 0.45 & 0.50 & 0.37 & 0.34 & 0.44 & 0.35 & 0.66
\end{tabular}

0

0

0

0

0

$0.04 \quad 0$

$0.04 \quad 0$

$0.04 \quad 0$

$0.04 \quad 0$

$0.04 \quad 0$

$0.04 \quad 0$

$0.04 \quad 0$

$0.04 \quad 0$

$0.04 \quad 0$

0.040

$5.00 \quad 0$

0.150

$\begin{array}{cccccccc}0 & 0 & 0 & 0 & 0 & 0 & 0.73 & 0 \\ 100.4 & 100.0 & 100.0 & 100.0 & 100.0 & 100.0 & 100.0 & 100.0\end{array}$ 


\section{EXPIANATION OF DATA 6}

Most of the data used in the table is from the following sources: The national income, in the country's respective currency, is for 1960, and derived from the United Nations Yearbook of National Accounts Statistics (1961) (hereinafter referred to as U.N. Yearbook) and the U.N. Monthly Bulletin of Statistics (Dec. 1962). The national income figures were converted into U.S. dollars by applying the 1960 exchange rates from the International Monetary Fund's Schedule of Par Values or Pick's Currency Yearbook (1960). Population is for 1960, from the United Nations Demographic Yearbook (1961). The United Nations percentage figure is the present 1962/1964 U.N. assessment scale percentage, except that $0.04 \%$ is assumed for the newest U.N. members. Because no complete set of data for all countries could be found, data for the more significant countries missing from the sources cited above was gleaned from a variety of other sources (in parentheses) as follows:

China: For Mainland China, the 1957 national income figure (The China Quarterly, Jan. 1960) was coupled with the growth rate (U.N. Yearbook) to derive the 1960 national income. The China national income in U.S. dollars was then calculated by applying a .417 exchange rate. Added to this is the Taiwan 1960 national income (U.N.Yearbook) computed at an exchange rate of .027 (Pick's Currency Yearbook, 1960).

Cuba: 1960 national mcome derived hy applying the growth rate to 1958 national income (U.N. Yearbook).

Czechoslovakia: 1960 national income derived by applying the growth rate to $1956 \mathrm{na}-$ tional income (U.N.Yearbook, 1957).

Indonesia: 1960 national income derived by applying the growth rate to 1959 national income $(U . N$. Yearbook).

Morocco: 1960 national income derived by applying the growth rate to 1958 national income ( $U . N$. Yearbook).

Sweden: 1960 national income is an estimated $92 \%$ of 1960 gross domestic product (U.N. Yearbook), which was the only 1960 figure available for Sweden. The 92\% estimate was ascertained by analyzing five comparable European countries and arbitrarily taking an average as indicative of the relationship between national income and gross domestic product.

United Arab Republic: 1960 national income derived by applying the growth rate to 1956 national income (U.N. Yearbook).

U.S.S.R.: Comparison of U.S. and U.S.S.R. national incomes is extremely difficult and economists generally hazard only the most general guesses. Use of the 1960 U.N.Yearbook figure, 147 billion rubles, with any exchange rate found, results in a figure that produces a percentage in the scale completely different from the U.S.S.R. present scale percentage. Consequently, other means were used here to estimate U.S.S.R. national income. In a paper delivered to the Joint Economic Committee of the Umited States Congress, 7 Morris Bornstem of the University of Michigan suggested as a possible comparison that the U.S.S.R. in 1955 had about $38 \%$ of the national income of the U.S. Using this rough approximation for 1960, an arbitrary assumption, a figure of $\$ 157$ billion (38\% of U.S. national income of $\$ 413$ billion) can be "guessed" for the U.S.S.R. When used with U.N. scale computations (Scale No. 1) this produced a U.S.S.R. percentage of $17.79 \%$, compared with the U.N. scale percentage of $17.47 \%$. Consequently, this is the figure used. This figure is the weakest link in all the computations, and unfortunately affects the percentage of most of the other countries in the scale. The U.S.S.R. figures include Byelorussian S.S.R. and Ukrainian S.S.R. figgures, although these two States are technically separate members of the U.N.

6 The author appreciates the able research assistance of Stanley Skinner, Charles E. Sherman, and Kent Mitchell, second year students at Boalt Hall, who assisted in the compilation, preparation, and computation of the data.

7 Jont Economic Comanttee, 86rh Cong., 1St Sess., Comparisons of the United States and Soviet Econommes, pt. II, at 377 (Joint Comm. Print 1960). 